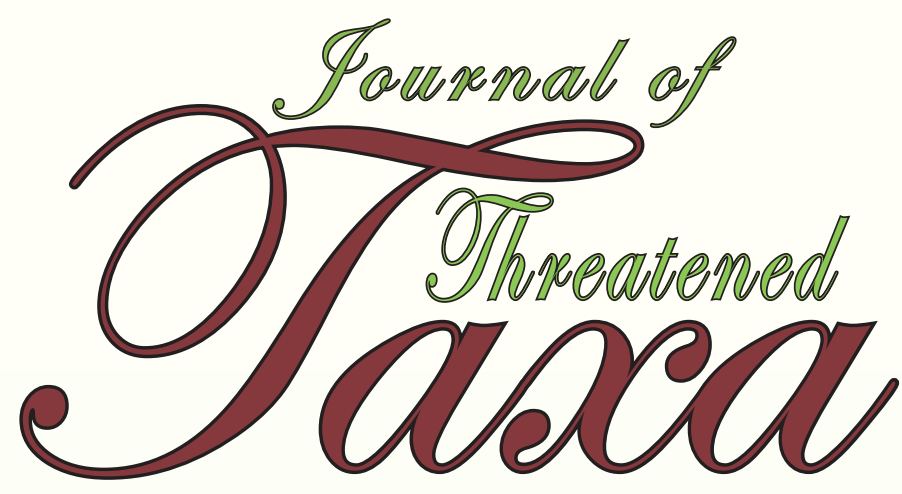

10.11609/jott.2021.13.14.20143-20310 evever.threatenedtaxa.org

26 December 2021 (Online \& Print) Val. 13 | Na. 14 | Pages: 20143-20310 155n 0974-7907 (Online) 155n 0974-7893 (Print)

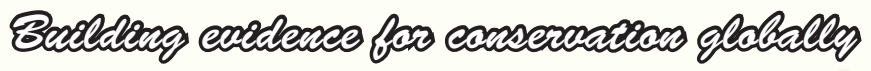
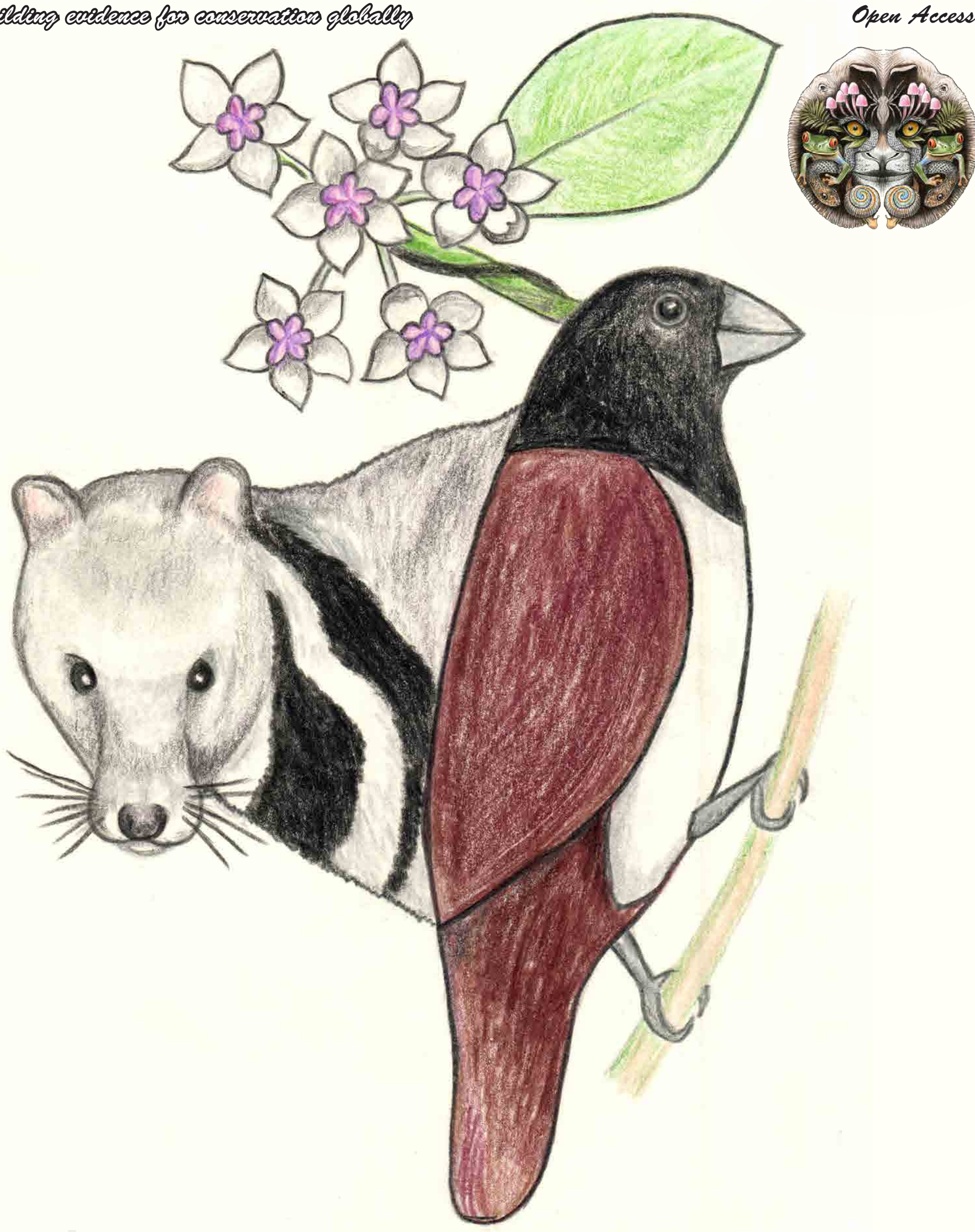


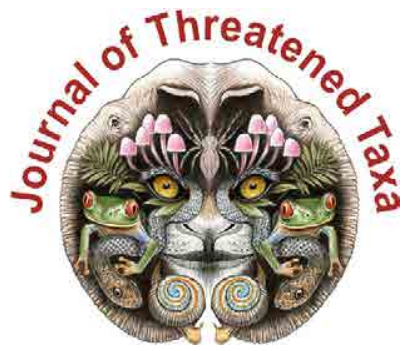

ISSN $0974-7907$ (Online); ISSN $0974-7893$ (Print)

Publisher

Wildlife Information Liaison Development Society

www.wild.zooreach.org

Host

Zoo Outreach Organization www.zooreach.org

No. 12, Thiruvannamalai Nagar, Saravanampatti - Kalapatti Road, Saravanampatti, Coimbatore, Tamil Nadu 641035, India

Ph: +91 9385339863 | www.threatenedtaxa.org

Email: sanjay@threatenedtaxa.org

EDITORS

\section{Founder \& Chief Editor}

Dr. Sanjay Molur

Wildlife Information Liaison Development (WILD) Society \& Zoo Outreach Organization (ZOO),

12 Thiruvannamalai Nagar, Saravanampatti, Coimbatore, Tamil Nadu 641035, India

\section{Deputy Chief Editor}

Dr. Neelesh Dahanukar

Noida, Uttar Pradesh, India

\section{Managing Editor}

Mr. B. Ravichandran, WILD/ZOO, Coimbatore, India

\section{Associate Editors}

Dr. Mandar Paingankar, Government Science College Gadchiroli, Maharashtra 442605, India

Dr. Ulrike Streicher, Wildlife Veterinarian, Eugene, Oregon, USA

Ms. Priyanka Iyer, ZOO/WILD, Coimbatore, Tamil Nadu 641035, India

Dr. B.A. Daniel, ZOO/WILD, Coimbatore, Tamil Nadu 641035, India

\section{Editorial Board}

Dr. Russel Mittermeie

Executive Vice Chair, Conservation International, Arlington, Virginia 22202, USA

\section{Prof. Mewa Singh Ph.D., FASc, FNA, FNASc, FNAPsy}

Ramanna Fellow and Life-Long Distinguished Professor, Biopsychology Laboratory, and Institute of Excellence, University of Mysore, Mysuru, Karnataka 570006, India; Honorary Professor, Jawaharlal Nehru Centre for Advanced Scientific Research, Bangalore; and Adjunct Professor, National Institute of Advanced Studies, Bangalore

\section{Stephen D. Nash}

Scientific Illustrator, Conservation International, Dept. of Anatomical Sciences, Health Sciences Center, T-8, Room 045, Stony Brook University, Stony Brook, NY 11794-8081, USA

\section{Dr. Fred Pluthero}

Toronto, Canada

\section{Dr. Priya Davidar}

Sigur Nature Trust, Chadapatti, Mavinhalla PO, Nilgiris, Tamil Nadu 643223, India

\section{Dr. Martin Fisher}

Senior Associate Professor, Battcock Centre for Experimental Astrophysics, Cavendish

Laboratory, JJ Thomson Avenue, Cambridge CB3 OHE, UK

\section{Dr. John Fellowes}

Honorary Assistant Professor, The Kadoorie Institute, 8/F, T.T. Tsui Building, The University of Hong Kong, Pokfulam Road, Hong Kong

\section{Prof. Dr. Mirco Solé}

Universidade Estadual de Santa Cruz, Departamento de Ciências Biológicas, Vice-coordenador do Programa de Pós-Graduação em Zoologia, Rodovia Ilhéus/Itabuna, Km 16 (45662-000)

Salobrinho, Ilhéus - Bahia - Brasil

\section{Dr. Rajeev Raghavan}

Professor of Taxonomy, Kerala University of Fisheries \& Ocean Studies, Kochi, Kerala, India

\section{English Editors}

Mrs. Mira Bhojwani, Pune, India

Dr. Fred Pluthero, Toronto, Canad

Mr. P. Ilangovan, Chennai, India

Web Development

Mrs. Latha G. Ravikumar, ZOO/WILD, Coimbatore, India

\section{Typesetting}

Mr. Arul Jagadish, ZOO, Coimbatore, India

Mrs. Radhika, ZOO, Coimbatore, India

Mrs. Geetha, ZOO, Coimbatore India
Fundraising/Communications

Mrs. Payal B. Molur, Coimbatore, India

Subject Editors 2018-2020

Fungi

Dr. B. Shivaraju, Bengaluru, Karnataka, India

Dr. R.K. Verma, Tropical Forest Research Institute, Jabalpur, India

Dr. Vatsavaya S. Raju, Kakatiay University, Warangal, Andhra Pradesh, India

Dr. M. Krishnappa, Jnana Sahyadri, Kuvempu University, Shimoga, Karnataka, India

Dr. K.R. Sridhar, Mangalore University, Mangalagangotri, Mangalore, Karnataka, India

Dr. Gunjan Biswas, Vidyasagar University, Midnapore, West Bengal, India

\section{Plants}

Dr. G.P. Sinha, Botanical Survey of India, Allahabad, India

Dr. N.P. Balakrishnan, Ret. Joint Director, BSI, Coimbatore, India

Dr. Shonil Bhagwat, Open University and University of Oxford, UK

Prof. D.J. Bhat, Retd. Professor, Goa University, Goa, India

Dr. Ferdinando Boero, Università del Salento, Lecce, Italy

Dr. Dale R. Calder, Royal Ontaro Museum, Toronto, Ontario, Canada

Dr. Cleofas Cervancia, Univ. of Philippines Los Baños College Laguna, Philippines

Dr. F.B. Vincent Florens, University of Mauritius, Mauritius

Dr. Merlin Franco, Curtin University, Malaysia

Dr. V. Irudayaraj, St. Xavier's College, Palayamkottai, Tamil Nadu, India

Dr. B.S. Kholia, Botanical Survey of India, Gangtok, Sikkim, India

Dr. Pankaj Kumar, Kadoorie Farm and Botanic Garden Corporation, Hong Kong S.A.R., China

Dr. V. Sampath Kumar, Botanical Survey of India, Howrah, West Bengal, India

Dr. A.J. Solomon Raju, Andhra University, Visakhapatnam, India

Dr. Vijayasankar Raman, University of Mississippi, USA

Dr. B. Ravi Prasad Rao, Sri Krishnadevaraya University, Anantpur, India

Dr. K. Ravikumar, FRLHT, Bengaluru, Karnataka, India

Dr. Aparna Watve, Pune, Maharashtra, India

Dr. Qiang Liu, Xishuangbanna Tropical Botanical Garden, Yunnan, China

Dr. Noor Azhar Mohamed Shazili, Universiti Malaysia Terengganu, Kuala Terengganu, Malaysia

Dr. M.K. Vasudeva Rao, Shiv Ranjani Housing Society, Pune, Maharashtra, India

Prof. A.J. Solomon Raju, Andhra University, Visakhapatnam, India

Dr. Mandar Datar, Agharkar Research Institute, Pune, Maharashtra, India

Dr. M.K. Janarthanam, Goa University, Goa, India

Dr. K. Karthigeyan, Botanical Survey of India, India

Dr. Errol Vela, University of Montpellier, Montpellier, France

Dr. P. Lakshminarasimhan, Botanical Survey of India, Howrah, India

Dr. Larry R. Noblick, Montgomery Botanical Center, Miami, USA

Dr. K. Haridasan, Pallavur, Palakkad District, Kerala, India

Dr. Analinda Manila-Fajard, University of the Philippines Los Banos, Laguna, Philippines

Dr. P.A. Sinu, Central University of Kerala, Kasaragod, Kerala, India

Dr. Afroz Alam, Banasthali Vidyapith (accredited A grade by NAAC), Rajasthan, India

Dr. K.P. Rajesh, Zamorin's Guruvayurappan College, GA College PO, Kozhikode, Kerala, India

Dr. David E. Boufford, Harvard University Herbaria, Cambridge, MA 02138-2020, USA

Dr. Ritesh Kumar Choudhary, Agharkar Research Institute, Pune, Maharashtra, India

Dr. Navendu Page, Wildlife Institute of India, Chandrabani, Dehradun, Uttarakhand, India

\section{Invertebrates}

Dr. R.K. Avasthi, Rohtak University, Haryana, India

Dr. D.B. Bastawade, Maharashtra, India

Dr. Partha Pratim Bhattacharjee, Tripura University, Suryamaninagar, India

Dr. Kailash Chandra, Zoological Survey of India, Jabalpur, Madhya Pradesh, India

Dr. Ansie Dippenaar-Schoeman, University of Pretoria, Queenswood, South Africa

Dr. Rory Dow, National Museum of natural History Naturalis, The Netherlands

Dr. Brian Fisher, California Academy of Sciences, USA

Dr. Richard Gallon, llandudno, North Wales, LL30 1UP

Dr. Hemant V. Ghate, Modern College, Pune, India

Dr. M. Monwar Hossain, Jahangirnagar University, Dhaka, Bangladesh

Mr. Jatishwor Singh Irungbam, Biology Centre CAS, Branišovská, Czech Republic.

Dr. Ian J. Kitching, Natural History Museum, Cromwell Road, UK

Dr. George Mathew, Kerala Forest Research Institute, Peechi, India

For Focus, Scope, Aims, and Policies, visit https://threatenedtaxa.org/index.php/JoTT/aims_scope
For Article Submission Guidelines, visit https://threatenedtaxa.org/index.php/JoTT/about/submissions
For Policies against Scientific Misconduct, visit https://threatenedtaxa.org/index.php/JoTT/policies_various 


\title{
Updated distribution of seven Trichosanthes L. (Cucurbitales: Cucurbitaceae) taxa in India, along with taxonomic notes
}

\author{
Kanakasabapathi Pradheep ${ }^{1} \mathbb{D}$, Soyimchiten ${ }^{2} \mathbb{D}$, Ganjalagatta Dasaiah Harish ${ }^{3}$ (D), \\ Muhammed Abdul Nizar ${ }^{4} \mathbb{D}$, Kailash Chandra Bhatt ${ }^{5} \mathbb{D}$, Anjula Pandey ${ }^{6} \mathbb{D}$ \& Sudhir Pal Ahlawat ${ }^{7}$ \\ 1,2,5,6,7 Division of Plant Exploraton and Germplasm Collecton, ICAR-National Bureau of Plant Genetic Resources (ICAR-NBPGR), \\ New Delhi 110012, India. \\ ${ }^{3}$ ICAR-NBPGR, Regional Station, Umiam, Ri-Bhoi District, Meghalaya 793103, India. \\ ${ }^{4}$ ICAR-NBPGR, Regional Station, Opp. PDKV Campus, Akola, Maharashtra 444104, India. \\ ${ }^{1}$ Present Address: ICAR-NBPGR, Regional Station, Thrissur, Kerala 680656, India. \\ ${ }^{4}$ Present Address: "Mannath", 64/1249A, Judges Avenue, Kaloor, Ernakulam 682 017, India \\ ${ }^{1}$ k.pradheep@icar.gov.in (corresponding author), ${ }^{2}$ soyimchiten@icar.gov.in, ${ }^{3}$ harish.gd@icar.gov.in, ${ }^{4}$ m.nizar@icar.gov.in, \\ ${ }^{5}$ kailash.bhatt@icar.gov.in, ${ }^{6}$ anjula.pandey@icar.gov.in, ${ }^{7}$ sudhir.ahlawat@icar.gov.in
}

\begin{abstract}
In India, lack of revisionary work in the genus Trichosanthes L. (Cucurbitales: Cucurbitaceae) over the past 38 years had resulted in several taxonomic and nomenclatural issues, which had implications in determining actual distribution status of taxa. Based on field observations, collected specimens, data from various specimens in herbaria and critical study of all the resources available, here we confirm the extended distribution of T. anaimalaiensis Bedd. in the states of Manipur and Nagaland; T. cordata Roxb. in Uttar Pradesh and Bihar; T. cucumerina L. subsp. sublobata (Kundu) K. Pradheep, D.R. Pani \& K.C. Bhatt in Gujarat, Madhya Pradesh and Odisha; T. dicaelosperma C.B. Clarke in Nagaland; T. kerrii Craib in Arunachal Pradesh and Manipur; T. majuscula (C.B. Clarke) Kundu in Arunachal Pradesh, Sikkim and Assam; and T. truncata C.B. Clarke in Nagaland. Two taxa, namely, Trichosanthes dicaelosperma and T. majuscula, earlier subsumed with T. ovigera Blume or T. cucumeroides (Ser.) Maxim., and T. dunniana H. Lév., respectively, have been resurrected at the rank of species. Lectotypes were designated for the names of above two species. For the first time, female plants of $T$. majuscula have been described. This communication provides an updated distribution status of seven taxa of Trichosanthes in India along with field and taxonomic notes, and additional taxonomic characters.
\end{abstract}

Keywords: Lectotypification, new distribution records, northeastern India, range extensions, Trichosanthes dicaelosperma, T. majuscula.

Citation: Pradheep, K., Soyimchiten, G.D. Harish, M.A. Nizar, K.C. Bhatt, A. Pandey \& S.P. Ahlawat (2021). Updated distribution of seven Trichosanthes L. (Cucurbitales: Cucurbitaceae) taxa in India, along with taxonomic notes. Journal of Threatened Taxa 13(14): 20143-20152. https://doi.org/10.11609/jott.6313.13.14.20143-20152

Copyright: (c) Pradheep et al. 2021. Creative Commons Attribution 4.0 International License. JoTT allows unrestricted use, reproduction, and distribution of this article in any medium by providing adequate credit to the author(s) and the source of publication.

Funding: ICAR-Natonal Bureau of Plant Genetc Resources, New Delhi.

Competing interests: The authors declare no competing interests.

Author details: See end of this article.

Author contributions: $\mathrm{KP}-$ conceptualization, field trips, herbarium study, data generation, data analysis, writing the manuscript, images. $\mathrm{S}-$ field trips in Nagaland, Data generation, editing/correcting manuscript. GDH-field trips in Arunachal Pradesh, Data generation, editing/correcting manuscript. AN-field trips in Peninsular India, Data generation, editing/correcting manuscript. KCB-field trips in NE India, Data generation, editing/correcting manuscript. AP-herbarium study, Data generation, editing/correcting manuscript. SPA-data analysis, editing/correcting manuscript.

Acknowledgements: Authors are thankful to the director, ICAR-NBPGR, New Delhi for support rendered in the field as well as herbarium studies. Acknowledgements are also due to the authorities of various herbaria - ASSAM, BSD, BSHC, BSJO, CAL, DD, KASH, LWG, MH, NEHU, NHCP, PBL, PCM, and RHT for permitting herbarium consultation; and Ms. Rita Gupta, NHCP for the help in the incorporation of herbarium specimens in NHCP, ICAR-NBPGR, New Delhi.

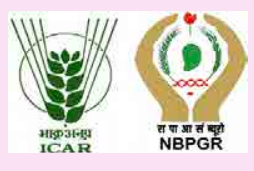




\section{INTRODUCTION}

Known as the largest genus in the family Cucurbitaceae, Trichosanthes L. consists of about 100 species with some having vegetable and medicinal importance, occurring from the Indian subcontinent in the west, to China and Japan in the north and the east, to Australia in the south (de Wilde \& Duyfjes 2010, 2012). Chakravarty (1982) and Renner \& Pandey (2013) had reported the occurrence of 22 species in India, with more than three-fourths occurring exclusively in the northeastern region of India. Incomplete herbarium collections in species-rich areas, dioecy, nocturnal flowering, heterophylly, and different juvenile morphology, together with the lack of recent revisionary works (since 1982) had resulted to taxonomic misidentifications and nomenclatural instability in the Indian taxa, which in turn led to non-detection of species in a given area, although present. Reporting of extended distribution of wild species related to crop species not only helps updating the floristic databases of the concerned region, but also in augmenting unrepresented germplasm from such regions for conservation and sustainable utilization (Pradheep et al. 2011, 2018).

\section{MATERIALS AND METHODS}

This study was based on extensive survey and explorations (23 trips) carried out all over India during 2009-2020 and herbarium studies. Senior author had personally visited various Indian herbaria - ASSAM, BSD, BSHC, BSIS, BSJO, CAL, CUH, DD, KASH, LWG, MH, NEHU, $\mathrm{NHCP}, \mathrm{PBL}, \mathrm{PCM}$, and RHT [herbaria codes according to Thiers (2020, continuously updated)]. Species geographic occurrence data from the Global Biodiversity Information Facility (GBIF) and various online herbaria - A, B, BM, BR, E, G, HIFB, FRLHT, GH, HBG, IIIM, JCB, K, KFRI, L, LINN, MO, NY, P, PE, and RPRC [herbaria codes according to Thiers (2020, continuously updated)], including type specimens were also consulted. All the specimens cited here were seen either as physical specimens or in the form of online digital images. Detailed observation on qualitative and quantitative characters was made and herbarium specimens were prepared as per standard procedure (Jain \& Rao 1977). Thorough verification or cross-checking with floristic as well as other key literature pertaining to the concerned state (Table 1) and other pertinent works (Jeffrey 1980, 1982; Chakravarty 1982; Naithani 1990; Renner \& Pandey 2013; Pradheep et al. 2014, 2015; Pandey et al.
2016) was made and the status of species distribution was updated. This resulted in identification of seven Trichosanthes species with extended distribution in various Indian states. While herbarium vouchers of these species were deposited in the National Herbarium of Cultivated Plants (NHCP) at ICAR-National Bureau of Plant Genetic Resources (ICAR-NBPGR), New Delhi, germplasm collections are being conserved in the form of (live) seeds in the National Genebank at ICAR-NBPGR, New Delhi.

\section{Taxonomic Enumeration \\ 1. Trichosanthes anaimalaiensis}

Bedd., Madras J. Lit. Sci. 3(1): 47. 1864. Chakravarty, Fasc. Fl. Ind. 11: 107. 1982. T. anamalayanus Bedd. Trans. Linn. Soc. 25: 217. 1865. T. palmata Roxb. var. tomentosa B. Heyne ex C. B. Clarke, Fl. Brit. Ind. 2(6): 607. 1879. T. burmensis Kundu, J. Bombay Nat. Hist. Soc. 43(2): 381. 1942. T. burmensis Kundu var. alba Kundu, J. Bombay Nat. Hist. Soc. 43(2): 381. 1942. T. bracteata (Lam.) Voigt var. tomentosa (B. Heyne ex C.B. Clarke) Chakrav., Rec. Bot. Surv. Ind. 17(1): 47. 1959; Chakravarty, Fasc. Fl. Ind. 11: 110. 1982. T. tricuspidata Lour. var. tomentosa (B. Heyne ex C.B. Clarke) Kumari, Fl. Tamil Nadu, Ind., Ser I: Analysis 1: 174. 1983.

Type: India, Tamil Nadu, Anaimalai Mts., Beddome 3234 (holotype BM, available at http://plants.jstor.org/ specimen/bm000885793).

Robust dioecious climber, 15-20 m long. Stems: robust, highly striate, grooved, puberulous, pale green; young twigs often reddish. Tendrils: $2-3$ fid, one strong. Probracts: elongate, tail-like, $1.5-2.0 \times 0.45 \mathrm{~cm}$, distantly irregularly serrate, reflexed. Leaves: petioles stout, 6-8 $\mathrm{cm}$ long, striate, puberulous; lamina membranous, ovate-suborbicular in outline, 12-17 $\times 13-18 \mathrm{~cm}$, shallowly 3-5-lobed, lobes rarely up to middle, upper lobe half-elliptic, base slightly cordate, adaxially bulbous-strigose, very scabrous, pale green, abaxially reticulate, tomentose on nerves, margin irregularly or deeply serrate, 4-5 nerved at base, glands 10-20, medium-sized, at base and along main nerves. Male racemes: 25-30 cm long, 5-8-flowered; peduncles very stout, grooved, puberulous; rachis \pm zigzag, withered bracts intact; bracts pale green, puberulous, cucullate, sub-reniform in outline, $3.5-4.2 \times 3.8-4.7 \mathrm{~cm}$, apex rotund, prominently corrugated, highly laciniatelacerate, nerves 12-15, glands 10-15. Male flowers: pedicel $0.6 \mathrm{~mm}$ long; flowers highly fragrant, $4-5.5 \mathrm{~cm}$ long, $0.35 \mathrm{~cm}$ diameter at base or $0.7-0.9 \mathrm{~cm}$ at mouth, calyx tube often pinkish-red, glands few. Sepals: gigantic, cucullate, ovate-triangular in outline (of female flower 


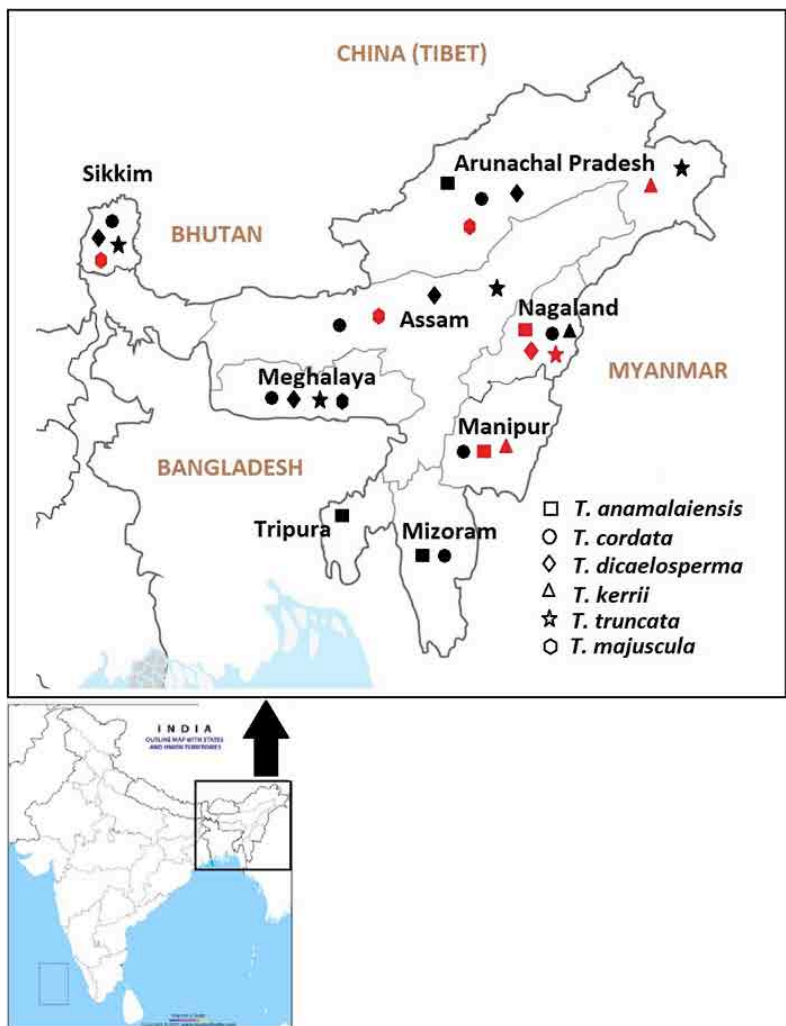

Figure 1. Occurrence of Trichosanthes anaimalaiensis, $T$. cordata, $T$. dicaelosperma, T. kerrii, T. majuscula and $T$. truncata in northeastern Indian states (black-filled shapes indicates already-reported, while red-filled ones are new distribution records)

- subulate, entire), $2-2.5 \times 1 \mathrm{~cm}$, pale pinkish, apex acuminate, margin laciniate or lacerate. Petals: $1.3 \times$ $1.2 \mathrm{~cm}$ (excluding frills, frills $0.5-0.7 \mathrm{~cm}$ long), adaxially whitish often with pink veins, hirsute. Anthers: stamens 3 , conduplicate, arise just above the rim of corolla tube, $11.5-12.5 \times 3-3.2 \mathrm{~mm}$; filaments short, $3 \mathrm{~mm}$ long, stout. Stigma lobes 3. Fruits: pedicels $2.3-2.7 \mathrm{~cm}$ long; fruits solitary, rarely in clusters (see notes), (sub) globose, 5-6 $\times 5-5.6 \mathrm{~cm}$, umbonate, pulp greenish black. Seeds: oblong, 9-10 × 4-5 × 1.5-2 mm, reddish, margin \pm angular (Image $1 \mathrm{~A} \& \mathrm{~B}$ ).

Flowering and fruiting: May-September and August-November, respectively.

Habitat: Evergreen broad-leaved forests up to 1,600 $\mathrm{m}$; found in red lateritic soils.

Distribution: India (Andhra Pradesh, Arunachal Pradesh, Karnataka, Kerala, Maharashtra, Mizoram, Tamil Nadu, and Tripura; new to Manipur and Nagaland (Figure 1)), Sri Lanka (Jeffrey 1982), and Myanmar (now).

Specimens examined: Manipur: 7162 (CAL), 29.ix.2012, Yumnam Khunou, Bishnupur dt., 780 m, Coll. G. Watt; 12-2 (NHCP), 28.ix.2012, Iroisema, Imphal West dt., 750 m, coll. K. Pradheep; 12-3 (NHCP), 30.ix.2012,
Table 1. Important literature consulted for cross-checking species occurrence in some Indian states.

\begin{tabular}{|c|l|l|}
\hline & State & References \\
\hline 1. & Arunachal Pradesh & Hajra et al. (1996); Dash \& Singh (2017) \\
\hline 2. & Assam & Kanjilal et al. (1938) \\
\hline 3. & Bihar & Haines (1921-25) \\
\hline 4. & Manipur & Singh et al. (2000) \\
\hline 5. & Nagaland & Mao et al. (2017) \\
\hline 6. & Odisha & Saxena \& Brahmam (1994-1996) \\
\hline 7. & Sikkim & Grierson \& Long (1984); Hara (1966) \\
\hline 8. & Uttar Pradesh & Khanna et al. (1999) \\
\hline 9. & West Bengal & Grierson \& Long (1984); Paul et al. (2015) \\
\hline
\end{tabular}
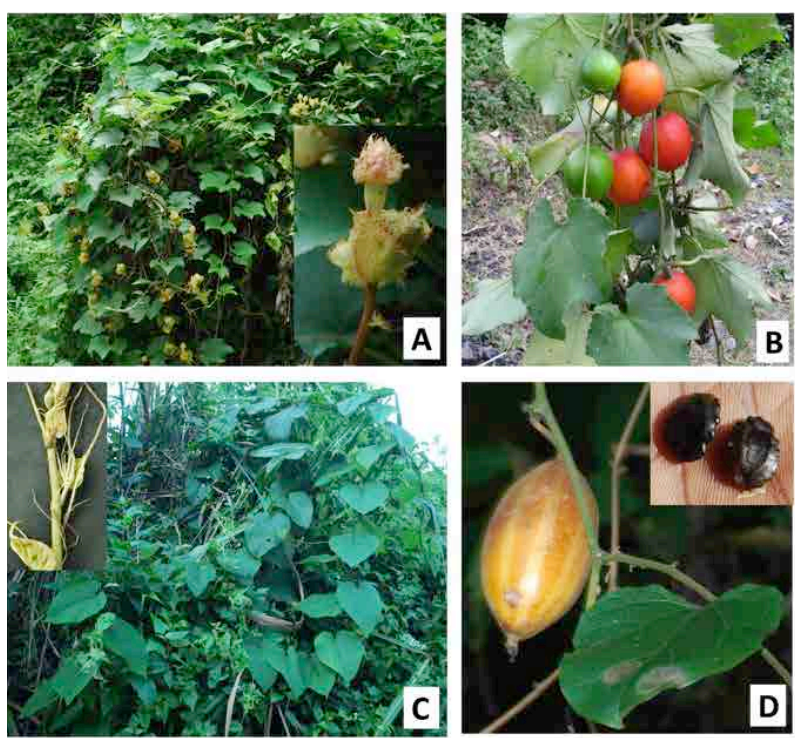

Image 1. A-Male plant of Trichosanthes anaimalaiensis in Nagaland (inset: bract and male flower bud) | B-Female plant of Trichosanthes anaimalaiensis in Nagaland | C-Habit of Trichosanthes kerrii in Arunachal Pradesh (inset: young twig) | D-Fruiting twig of Trichosanthes kerrii (inset: seeds). (C) K. Pradheep.

Kangla, Imphal East dt., 800 m, Coll. K. Pradheep; KP1263 (living coll. at NBPGR, New Delhi), 01.x.2012, Lilong, Thoubal dt., 780m, Coll. K. Pradheep. Nagaland: 14-1 (NHCP), 11.viii.2014, Chare, Tuensang dt., 1310 m, Coll. K. Pradheep \& Soyimchiten; 14-2 (NHCP), 12.viii.2014, Sangsangyu, Hakchang, Tuensang dt., 1350 m, Coll. K. Pradheep \& Soyimchiten; KC/S/I-67 (living coll. at NBPGR, New Delhi), 20.x.2011, Mirima, Kohima dt., $870 \mathrm{~m}$, Coll. K.C. Bhatt et al.

Notes: The striking character 'fruits borne in cluster', with which this species traditionally being distinguished from $T$. bracteata, is not a good taxonomic character. It is an unusual tendency of male inflorescence turning 
to female, hence retaining bracts; such a kind of sex reversal is of common occurrence in Cucurbitaceae in general, and Trichosanthes in particular (Rugayah 1999). In natural conditions as well as in herbaria, authors have come across such tendency in other species too - T. costata Blume, T. cucumerina subsp. sublobata, T. dicaelosperma, T. longispicata Rugayah, T. pilosa Lour., T. quinquangulata A.Gray, T. majuscula and $T$. tricuspidata Lour. This species is well distinguished from T. bracteata (Lam.) Voigt through tomentose nature of leaves (at lower surface), prominent probracts, pinkishred flowers, highly laciniate bracts and male sepals, and oblong seeds. In herbarium specimens, dried leaves appear dark brownish-red in colour.

Although C.B. Clarke (I.c.) (later Kundu 1943) agreed that T. palmata var. tomentosa deserves to be a good species with stable diagnostic characters, it appears that Clarke was unaware of $T$. anaimalaiensis, the species which had been published some 15 years back, therefore rule of priority favours latter as the accepted taxon. In agreement with Chakravarty (1959), type specimen (male specimen) study confirms the synonymization of $T$. burmensis and its var. alba with var. tomentosa (= T. anaimalaiensis); however ovoid-oblong fruit shape as mentioned in former's protologue indicates the possibility of erroneous choice of female specimens by Kundu in his herbarium-based study. Renner \& Pandey (2013) mentioned its distribution in Andaman \& Nicobar Islands, which is clearly outside its distributional range. A live collection (IC587669) at ICAR-NBPGR Base Centre, Cuttack, originally from Mayurbhanj district of Odisha had a close similarity with this species.

\section{Trichosanthes cordato}

Roxb., Fl. Ind. 3: 703. 1832. Clarke in Hook. f., FI. Brit. Ind. 2: 608. 1879; Prain, Beng. PI. 1: 363. 1903; Kanjilal et al., Fl. Assam 2: 328. 1938; Chakravarty, Fasc. Fl. Ind. 11: 110. 1982. T. macrosiphon Kurz, J. Asiat. Soc. Bengal, Pt. 2, Nat. Hist. 41: 308. 1872. T. cordata Roxb. var. subpedata C. B. Clarke. Fl. Brit. Ind. 2: 608. 1879.

Type: Icon. Roxb. 1691 (lectotype K, designated by Jeffrey (1980)), available at http://d2seqvvyy3b8p2. cloudfront.net/a9a143009a2e9f6f09529819e3230496. jpg

Dioecious; root tuberous. Stems: robust, angularsulcate, glabrous or puberulent. Tendrils: usually 3-fid, elongate, sulcate, puberulent. Leaves: petioles 8-15 cm long, striate, puberulent; lamina membranous, broadly cordate, $15-20 \times 15-20 \mathrm{~cm}$, papery, unlobed or rarely angular-sublobate, both surfaces shortly hirsute, apex acute or shortly acuminate, margin minutely denticulate.
Male racemes: $15-30 \mathrm{~cm}$ long, 6-10 flowered; rachis stout, striate, puberulent; bracts \pm glabrous, almost entire, oblong-ovate, $4-4.6 \mathrm{~cm}$ long as broad. Co-axillary male flower also present. Male flower: pedicels 1-2 mm long; calyx tube $4-5 \times 0.5-1 \mathrm{~cm}$, attenuate at apex and base, densely villose; sepals entire, linear-lanceolate, 13$15 \times 2-3 \mathrm{~mm}$; petals shortly papillose; Stamens: filaments glabrous; anthers 10-12 × 3-4 mm. Female flower: solitary, pedicel $1 \mathrm{~cm}$ long; ovary oblong, puberulent. Fruits: smooth, globose, red, orange-streaked, umbo absent, pulp greenish-black. Seeds: dark brown, oblong, 10-12 × 4-5 × 2-2.5 mm, subquadrangular, belted at middle, slightly angular in margin.

Flowering and fruiting: May-September and August-November, respectively.

Habitat: Occasional in evergreen broad-leaved forest edges/clearings, scrub jungles, Terai areas; 300-1,200 $\mathrm{m}$.

Distribution: India (Arunachal Pradesh, Assam, Manipur, Meghalaya, Mizoram, Nagaland, Sikkim, Uttarakhand, and West Bengal (Figure 1), new to Uttar Pradesh and Bihar), Bangladesh, Bhutan, China, India, Myanmar, and Nepal.

Specimens examined: Bihar: 424 (CAL), 12.ix.1965, Naurangia, (West) Champaran dt., Coll. S.P. Banerjee. Uttar Pradesh: 252617 (LWG), 22.x.2010, Nishangara forest, Katarniyaghat WLS, Bahraich dt., Coll. S.D. Maliya (Image 2); EBH 73 (LWG), 08.viii.1979, Chandar Chowk, Lakhimpur-Kheri dt., Coll. S. Saha et al.; EBH 93 (LWG), 08.viii.1979, Bela Parsua, Kheri dt., Coll. J.K. Maheswari et al.

Notes: Notwithstanding the lectotypification (of Roxburgh's drawing) by Jeffrey (1980) for this species, Chakravarty (1982) and Renner \& Pandey (2013) mentioned the herbarium specimen, Wall. Cat. 6686A, housed at K (K001124519) as its 'type'. They further mentioned its distribution in Andhra Pradesh, Chhattisgarh, Jharkhand, Madhya Pradesh, Rajasthan, and Tamil Nadu, which is clearly out of its range, and is based on misidentified specimens quoted in the earlier works, for instance, Kundu (1943) and Chakravarty (1959). As this species is well documented in Dehradun (Uttarakhand) in the west (Babu 1977) and Sikkim/ Darjeeling in the eastern side (Chakravarty 1982), it is expected to occur in the in-between areas falling under the states of Uttar Pradesh and Bihar adjoining to Nepal border. Although Chakravarty (1982) and Renner \& Pandey (2013) mentioned its distribution in Uttar Pradesh/Bihar, they didn't attribute to any evidence or herbarium details. Studied herbarium specimens from Bihar and Uttar Pradesh (see 'Specimens examined') 


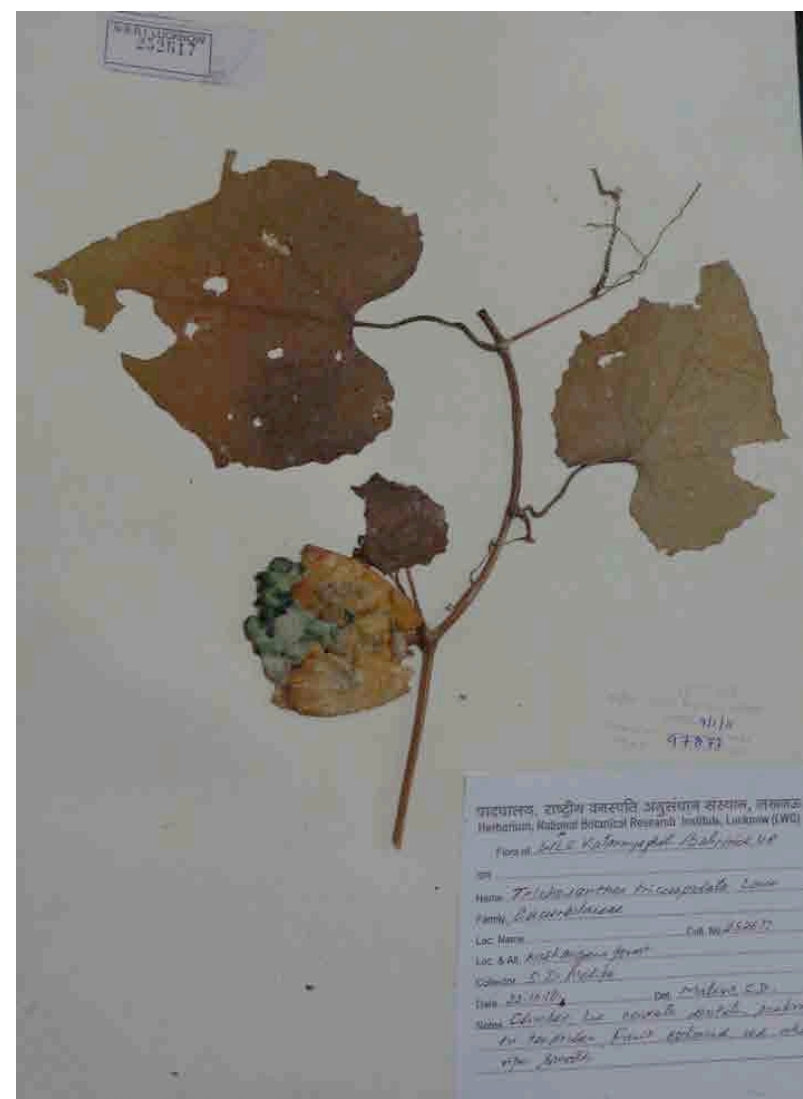

Image 2. Herbarium specimen of Trichosanthes cordata from Uttar Pradesh at LWG. @ Director, CSIR-NBRI, Lucknow.

were wrongly identified as $T$. bracteata in respective herbaria.

\section{Trichosanthes cucumerina L. subsp. sublobata}

(Kundu) K. Pradheep, D.R. Pani \& K.C. Bhatt, Novon 24(1): 41. 2015. T. brevibracteata Kundu var. sublobata Kundu, J. Bot. 77: 11. 1939.

Type: India, Nagpur-Wardha, Central Province, ix.1912, H.H. Haines 3295 (holotype K).

Monoecious, annual climber. Leaves: petioles 4-5 cm long, puberulous; lamina 7-11 × 7-12 cm, shallowly 3 -angled or lobed, parrot-green in colour, margins repand, toothed, denticulate, puberulous on both surfaces. Male racemes: puberulous, up to $9 \mathrm{~cm}$ long, 6-10 flowered; bracts up to $4 \mathrm{~mm}$ long, often 3-lobed. Male flower: pedicels 3-15 $\mathrm{mm}$ long, shorter than the associated flower; calyx tube 15-17 mm long, apex stout; sepals 2-4 mm long; petal fringes highly divided. Female flowers: solitary; ovary narrowly elliptic. Fruits: pedicels $2-5 \mathrm{~cm}$ long; fruits ovate, $3-4.5 \mathrm{~cm}$ long, unripe ones pale green, broadly white-striped, apex strongly beaked, turn orange-red on ripening. Seeds: dark brown, flat, edges toothed-undulate, interspersed in scarlet-red

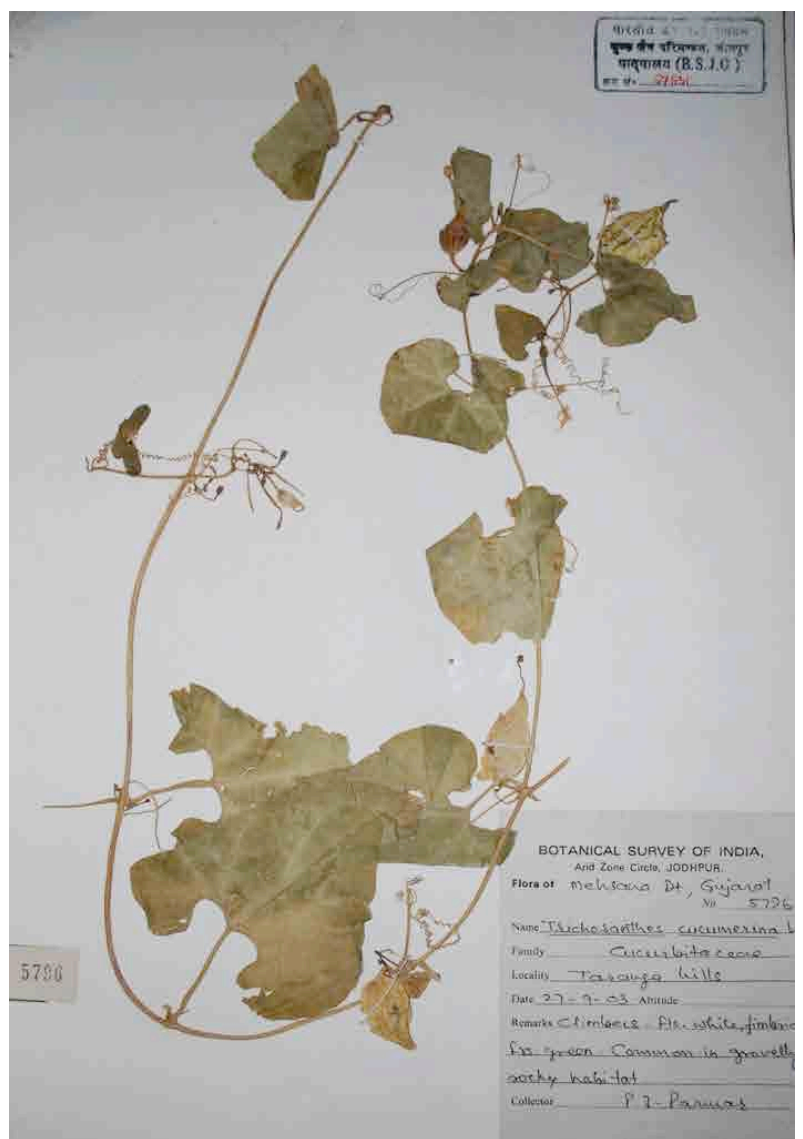

Image 3. Herbarium specimen of Trichosanthes cucumerina subsp. sublobata from Gujarat at BSJO. (C) Director, BSI, Kolkata.

pulp.

Flowering and fruiting: August-September and October-November, respectively.

Habitat: In herbaria, it was mentioned to have a common occurrence in wastelands and gravelly rocky areas, up to $400 \mathrm{~m}$.

Distribution: Endemic to central and western parts of India (Goa, Maharashtra; new to Gujarat, Madhya Pradesh, and Odisha).

Specimens examined: Gujarat: 5796 (BSJO), 27.ix.2003, Taranga Hills, Mehsana dt., Coll. P.J. Parmar (Image 3); 18095 (BSJO), 19.08.2003 Amirgarh Hills, Banaskantha dt., 300 m, Coll. S.L. Meena; 18218 (BSJO), 23.08.2003, Jessore WLS, Coll. S.L. Meena. Odisha: 5852 (MH), 19.viii.1931, Pachidya, Ganjam dt., Coll. V. Narayanaswami. Madhya Pradesh: Ratapani WLS, Raisen dt., https://www.flickr.com/photos/dinesh_ valke/9971030404/

Notes: Originally reported from Ratnagiri, Mumbai and Wardha districts of Maharashtra (Pradheep et al. 2015), this taxon was subsequently spotted in adjoining districts of Thane, Raigad (based on Flickr photos) of this 
state. Older collections were kept as subsp. cucumerina, from which it is easily distinguished by leaves being parrot green in colour, conspicuous bracts in staminate inflorescence and pale-green broadly white-striped unripe fruits and strongly beaked fruit apex.

\section{Trichosanthes dicaelosperma}

C.B. Clarke, Fl. Brit. Ind. 2: 609. 1879. Chakravarty, Fasc. Fl. Ind. 11: 113. 1982. T. cucumeroides (Ser.) Maxim. var. dicaelosperma (C.B. Clarke) S.K. Chen, Bull. Bot. Res., Harbin 5(2): 118. 1985.

Type (lectotype, designated here): India, Meghalaya, Khasia Hills, 4000 ft, 13.vii.1850, J.D. Hooker \& T. Thomson 1495 (K [digital image K000742692]; isolectotype, CAL0000015132)

Dioecious twinning climber. Stems: long, slender, sulcate, puberulent. Tendrils: 2-fid, stout, puberulent. Leaves: petioles $3-5 \mathrm{~cm}$ long, striate, shortly villose; lamina membranous, cordate-ovate, 8-15 × 6.5-11 $\mathrm{cm}$, unlobed, lower surface brown-nerved, apex acute-acuminate, nerves tomentose, margin minutely denticulate. Male inflorescences: paired, one early 1-flowered, other racemose, 6-10 cm long, 7-10 flowered, puberulent; bracts minute. Male flowers: pedicels $0.5-2.0 \mathrm{~cm}$ long; calyx tube $2.5-3 \mathrm{~cm}$ long, narrow, apex dilated, 3-4 $\mathrm{mm}$ long, pubescent, lobe spreading, subulate, $\pm 2 \mathrm{~mm}$ long. Female flower: pedicel 0.5-1 cm long; ovary oblong, shortly densely villose. Fruits: immature ones pubescent, 10 pale longitudinal banded, orange-red on ripening; ripe ones globose, 4-5 cm diameter, pulp scarlet-red. Seeds: dark-brown, much compressed, 7-9 × 8-9 × $3 \mathrm{~mm}$, subquadrate, equally 3-celled, lateral cells empty, base appendiculate.

Flowering and fruiting: August-September and September-November, respectively.

Habitat: Occasional in subtropical dense broadleaved forests, from 850-1,500 m.

Distribution: India (Arunachal Pradesh, Sikkim, West Bengal (Darjeeling) and Meghalaya; new to Nagaland (Figure 1)), Bhutan, China, and ?Myanmar.

Specimens examined: Nagaland: 101 (NEHU), Mokokchung, Coll. P.B. Gurung (Image 4).

Notes: While choosing lectotype (J.D. Hooker \& T. Thomson 1495, K000742692) according to ICN Article 9.3. and Recommendation 9A.3. (Turland et al. 2018), we have taken into consideration Clarke's annotation on herbarium sheet depicting his justification for new species. Besides, this sheet represents both the male and female plant parts depicting characters of taxonomic value. Renner \& Pandey (2013) synonymised this species under an East Asian species T. cucumeroides
Maxim., whereas Grierson \& Long (1991) kept under southeastern Asian T. ovigera Blume. In agreement with Chakravarty (1982), here we recognise T. dicaelosperma as a distinct species owing to unlobed leaves, globose fruits, scarlet-red pulp and flat subquadrate seeds. Immature fruits emanate odour similar to that of snake gourd. Renner \& Pandey (2013), Chakravarty (1982) and Khanna et al. (1999) reported its occurrence in Uttar Pradesh, which is clearly out of its distribution range and no authentic specimens available to substantiate. Though type specimens (CAL0000015132, K000742692) and other specimens (K000742694, L2988267, P03693959) were collected from Khasi Hills of Meghalaya some 150 years back, sincere efforts made to locate this species in original habitats were futile, possibly due to the extensive changes in landscape over the years; also not a single collection available in various herbaria visited. In Arunachal Pradesh, Hajra et al. (1996) reported this species only from Kameng, however we found its common occurrence in eastern parts of the state, i.e., Anjaw, Dibang Valley, and Lohit districts.

\section{Trichosanthes kerrii}

Craib, Bull. Misc. Inform. Kew 1: 7. 1914. Duyfjes \& Pruesapan, Thai For. Bull. Bot. 32: 87. 2004; W.J. de Wilde \& Duyfjes, FI. Thailand 9(4): 523. 2008; Huang \& Jeffrey in Lu \& Jeffrey, Fl. China 19: 39. 2011. T. tomentosa Chakrav., J. Bombay Nat. Hist. Soc. 50(4): 894. 1952; Chakravarty, Fasc. FI. Ind. 11: 121. 1982.

Type: Thailand, Nan, 25.ii.1912, 3,500 ft, A.F.G. Kerr 2454 (holotype K [K000742680, digital image]; isotype BM [BM000944641, digital image]).

Dioecious gigantic perennial climber. Stems: robust, elongate; twigs dark brown-yellowish, long hairy. Tendrils: 3-5 fid. Probracts: absent. Leaves: petioles robust, brown-tomentose, 5-12 cm long; lamina membranous, entire (unlobed), cordate-ovate in outline, $12-25 \times 10-20 \mathrm{~cm}$, base cordate, apex acuminate with caudate tip, upper surface deep green, short hirsute, occasionally with small white specks, lower surface fine reticulate, densely felty villose, margin entire, glands not obvious. Male inflorescences and female flowers not seen. Fruits: pedicels 3-5 cm long; fruits ellipsoid, 7-10 $\times$ 6-7 cm, orange, longitudinally pale-striped, glabrescent, pulp creamy yellow. Seeds dark brown, compressed, broad-elliptic, 11-13 × 9-10 × c. $3 \mathrm{~mm}$, base rounded, apex truncate, edges shallowly undulate or crenate (Image 1C \& D).

Flowering and fruiting: February-April and September-December, respectively.

Habitat: Forest edges along streams; 1,100-1,400 m. 


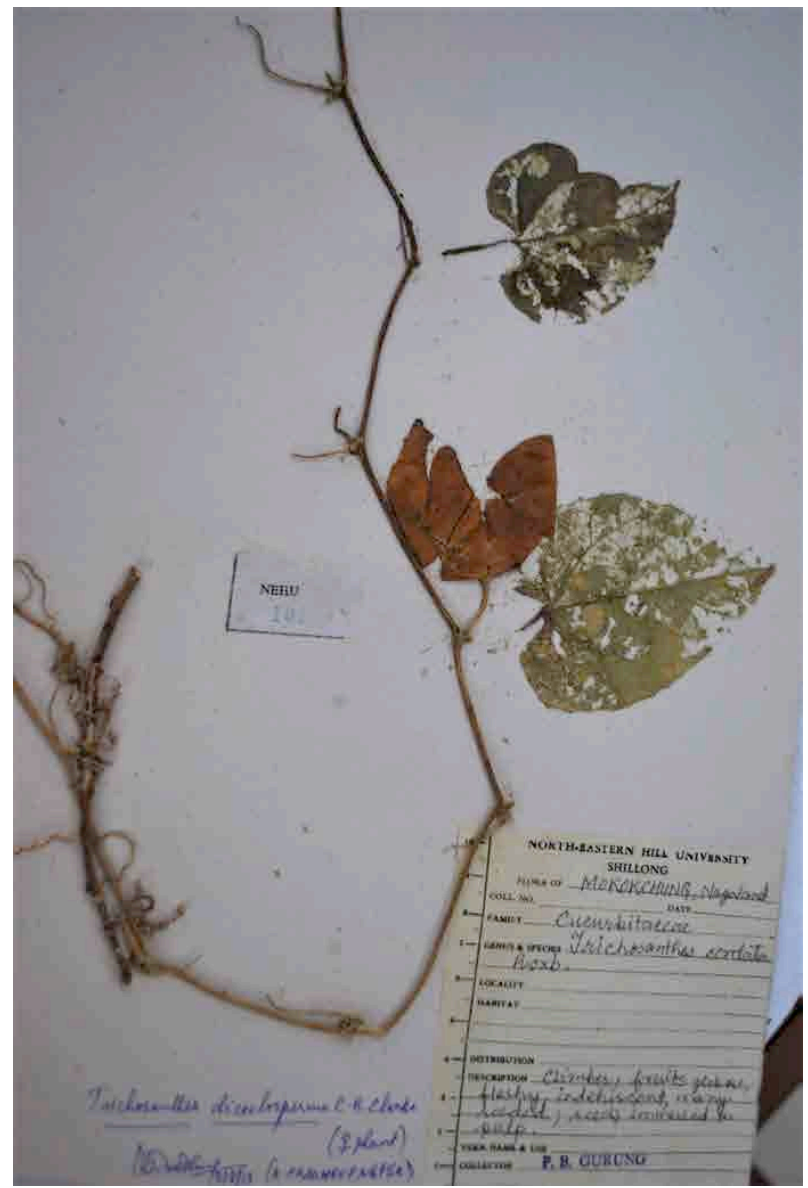

Image 4. Herbarium specimen of Trichosanthes dicaelosperma from Nagaland at NEHU. (C) NEHU, Shillong.

Distribution: India (Nagaland; new to Arunachal Pradesh and Manipur (Figure 1)), Laos, Myanmar, Thailand, and Vietnam.

Specimens examined: Arunachal Pradesh: 7023 (ASSAM), Tirap F.D., Coll. Panigrahi; 16-1 (NHCP), 27.x.2016, Lalpani, Lohit dt., 1,200 m, Coll. K. Pradheep \& G.D. Harish. Manipur: 6508 (CAL), xi.1907, Saithu, $3500 \mathrm{ft}$, Coll. A. Meebold.

Notes: In Nagaland, apart from Mokokchung (originally known from India from this district only), it is commonly found in Mon (vern. 'okhapatchechui') and Longleng districts, and occasional in Wokha and Tuensang districts. Senior and third authors observed this species also from Dibang Valley in Arunachal Pradesh. Long strigose hairs over the stem and petioles, and dense tomentose hairs over leaf surface at once distinguish it from other species. White stripes over fruits are retained even at dead-ripe stage. A fasciationlike disease symptom was observed on the plants in Mon district of Nagaland, similar observation also made in the herbarium collection (L2995297) from northern

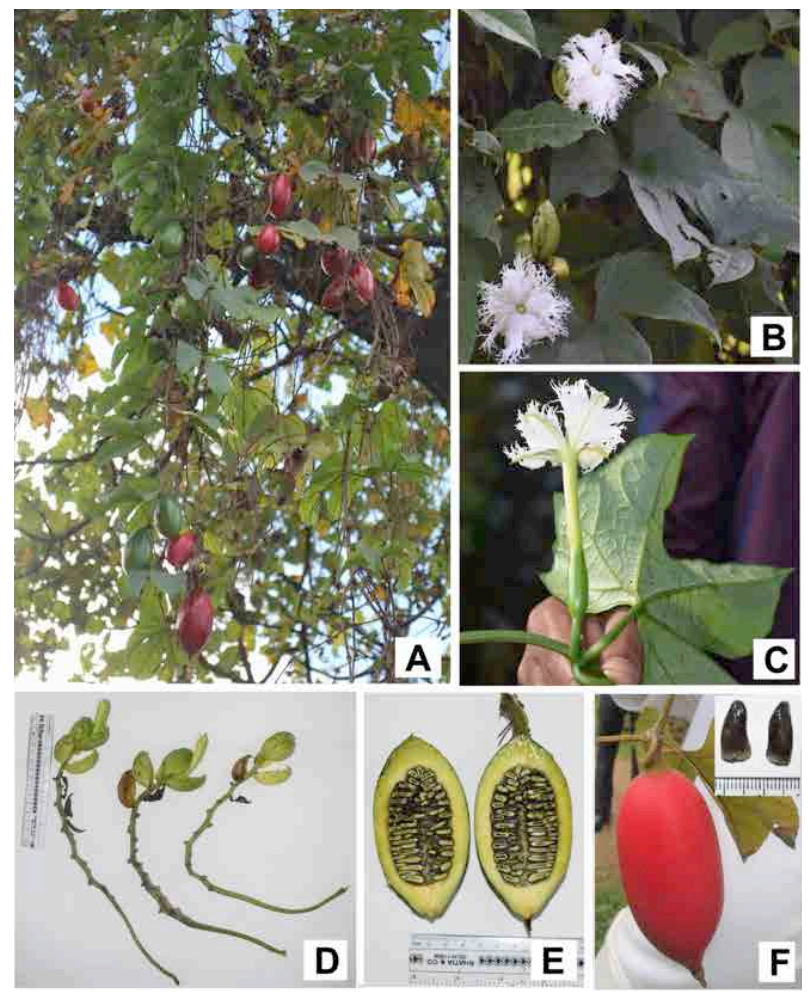

Image 5. Trichosanthes majuscula: A-Fruiting plant | B \& CFlowering twigs of male and female plants, respectively | DDetached male inflorescence | E-Longitudinal section of immature fruit | F-Ripe fruit (inset: seed). (C K. Pradheep.

Thailand.

\section{Trichosanthes majuscula}

(C.B. Clarke) Kundu, J. Bot. 77: 12. 1939. J. Bombay Nat. Hist. Soc. 43(2): 378. 1942; Chakravarty, Fasc. FI. Ind. 11: 118. 1982. T. multiloba Miq. var. majuscula C. B. Clarke in Hook.f., Fl. Brit. Ind. 2: 608. 1879. T. wallichiana (Ser.) Wight var. majuscula (C. B. Clarke) Cogn. in A. \& C. DC., Monog. Phan. 3: 369. 1881.

Type (lectotype, designated here): India, Meghalaya, Khasia Hills, 4,000 ft, J. D. Hooker \& T. Thomson s.n. (K [digital image K000742692]; isolectotype, K000036897 [digital image])

Perennial woody dioecious climber. Stems: robust, sulcate-striate, glabrous; twigs always green. Tendrils: very robust, woody, 3-fid. Probracts: ovate, $0.6 \times 0.4 \mathrm{~cm}$, green, crenulate, punctate. Leaves: petioles sulcate, $6-8$ $\mathrm{cm}$ long; lamina 15-20(-23) × 15-20 cm, membranous, \pm glabrous on both surfaces, abaxially pale green, deeply $3(-5)$-lobed with 2 mild side lobes, main lobes ellipticobovate, cuspidate, narrow towards base, leaf base (sub-)truncate to cordate, margins \pm undulate-crenate, glands few, small, scattered over main nerves. Male 


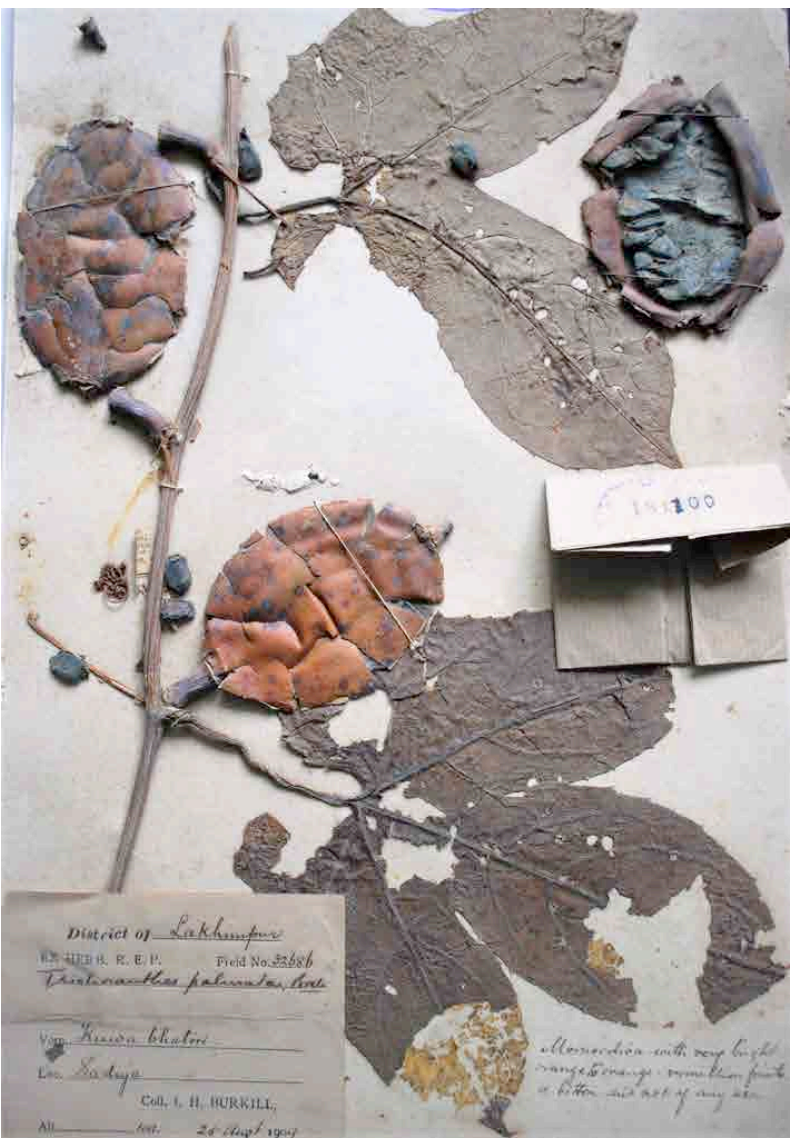

Image 6. Herbarium specimen of Trichosanthes majuscula from Assam at CAL. (C) Director, BSI, Kolkata.

inflorescences: thick, accrescent; peduncles striate, 8-10 $\mathrm{cm}$ long, rachis 20-26(-30) cm long, (13-)15-20(-24) flowered; bracts oblong, cymbiform, punctuate, margin obscurely and finely serrate at least above middle. Flowers: $8 \times 4-5 \mathrm{~cm}$, mildly fragrant; pedicels very short; calyx lobe $1 \times 0.5 \mathrm{~cm}$, entire, triangular-lanceolate, calyx tube $5.5-6.3 \mathrm{~cm}$ long, widening abruptly from $2 / 3^{\text {rd }}$ length towards apex, inside white-hairy; anthers $3(2+1), 0.4 \mathrm{~cm}$ wide, filaments $0.7 \mathrm{~cm}$ long. Female flowers: pedicels $0.8-1.3 \mathrm{~cm}$ long; calyx tube $5-6 \mathrm{~cm}$ long, tubular, slightly broad at apex; sepals $0.7 \mathrm{~cm}$ long, entire; ovary oblong, $1.4-1.6 \times 0.8 \mathrm{~cm}$, conspicuously grooved longitudinally; style $3 \mathrm{~cm}$ long; stigma lobes 3, greenish, $2.5 \mathrm{~mm}$ wide. Fruits: pedicels stout; fruit oblong-ovate, reddish on ripening, mesocarp thick, pulp (endocarp) greenish black. Seeds: 70-100, dark brown, ovate-oblong, $12-13.5 \times 7.6-8.2 \times 2.5-2.8 \mathrm{~mm}$, flat, often with raised central line, \pm angular (Images $5 \& 6$ ).

Flowering and fruiting: August-October and September-November, respectively.

Habitat: Common in forest edges in Meghalaya; occasional in Assam and Arunachal Pradesh; rare in
Sikkim; (200-)400-1,400 m.

Distribution: India (Meghalaya; new to Assam, Arunachal Pradesh and Sikkim (Figure 1)) and probably also in Bhutan.

Specimens examined: Arunachal Pradesh: 20045 (ASSAM), 12.x.1959, Nampang-Pangsu Pass, Tirap dt., Coll. R.S. Rao; 1107 (NHCP; living coll. at NBPGR, New Delhi), 18.x.2011, Napit, East Siang dt., Coll. K. Pradheep \& P.K. Singh; 1114 (living coll. at NBPGR, New Delhi), 19.x.2011, Ranaghat, East Siang dt., 252 m, Coll. K. Pradheep \& P.K. Singh; 1156 (NHCP), 18.x.2011, Kabali, Lower Dibang Valley dt., Coll. K. Pradheep \& P.K. Singh; 1157 (living coll. at NBPGR, New Delhi), 18.x.2011, Kabali, Lower Dibang Valley dt., 420 m, Coll. K. Pradheep \& P.K. Singh; 2677 (NHCP), 27.x.2017, Kornu (Roing), Lower Dibang Valley dt., Coll. K. Pradheep, R.S. Rathi \& G.D. Harish; 11-2 (NHCP), 21.x.2011, Chowkham, Lohit dt., Coll. K. Pradheep \& P.K. Singh; 1140 (NHCP), 22.x.2011, Tengapani RF, Lohit dt., Coll. K. Pradheep \& P.K. Singh; 1146 (NHCP), 24.x.2011, Parasuram Khund, Lohit dt., Coll. K. Pradheep \& P.K. Singh. Assam: 32686 (CAL), 25.viii.1909, Sadiya, Lakhimpur dt., Coll. I.H. Burkill; 39364 (ASSAM), viii.1984, Nakhola, Sonaikushi RF, Nowgong dt., Coll. N. P. Balakrishnan; 18-24 (NHCP), 22.ix.2018, Bijoy Nagar, Kamrup dt., Coll. K. Pradheep; 18-23 (NHCP), 19.ix.2018, Rangjuli, Goalpara dt., Coll. K. Pradheep; 1120 (NHCP), 20.x.2011, Simon Chapori, Dhemaji dt., Coll. K. Pradheep \& P. K. Singh. Sikkim: 18-15 (NHCP), 13.viii.2018, Kokaley, East Sikkim dt., 813 m, Coll. K. Pradheep; 18-16 (NHCP), Lower Thuminicola, East Sikkim dt., 976 m, Coll. K. Pradheep.

Notes: Out of available syntypes (K000742686, K000036897 and P06393544), former two were selected as lectotype and isolectotype (following Articles 9.3. and 9.12. of ICN; Turland et al. 2018) since Clarke himself annotated on these sheets as "Trichosanthes multiloba Miq. var. majuscula", in addition, they depict inflorescence characters such as thick and woody rachis, flowers borne from near the base, all of taxonomic value. This distinct species was originally described at reduced rank under a Japanese species T. multiloba, thereafter kept under T. wallichiana by A. Cogniaux (I.c.), later on synonymised under $T$. dunniana $\mathrm{H}$. Lév. by Jeffrey (1982), which was adopted by Huang \& Jeffrey (2011) and Renner \& Pandey (2013). Probable reason for this confusion is the lack of details on female flowers, fruits and seeds. It is easily distinguished from T. wallichiana by membranous leaves (vs. chartaceous), small ovate probracts (vs. much elongate), shorter peduncle of male inflorescences (vs. very long), serrate male bracts (vs. laciniate), ovate-oblong fruits (vs. globose) and dark 
brown seeds (vs. greenish-brown). From T. dunniana, it is different in being robust climber (vs. medium climber), large-sized leaves with 3(-5) lobes (vs. small with 5(-7) deep lobes), cymbiform bract (vs. cucullate), oblong ovary (vs. ovate) and big flat seeds with angular ends (vs. small, only slightly compressed with rounded ends).

\section{Trichosanthes truncata}

C.B. Clarke, Fl. Brit. Ind. 2: 608. 1879. Kanjilal et al., FI. Assam 2: 328. 1938; Chakravarty, Fasc. FI. Ind. 11: 122. 1982; S.K. Chen, FI. Yunnan 6: 364. 1995; Duyfjes \& Pruesapan, Thai For. Bull. Bot. 32: 99. 2004; W. J. de Wilde \& Duyfjes, Fl. Thailand 9(4): 537. 2008; Huang \& Jeffrey in Lu \& Jeffrey, Fl. China 19: 39. 2011. T. ovata Cogn. in A. \& C. DC., Monogr. Phan. 3: 365. 1881; Chakravarty, Fasc. FI. Ind. 11: 120. 1982; S.K. Chen, FI. Yunnan 6: 364. 1995.

Type: J.D. Hooker \& T. Thomson 1188, Khasia Hills, Meghalaya, India, (lectotype K, designated by Duyfjes \& Pruesapan (2004)).

Liana-forming dioecious climber. Stems: robust, angular-striate, glabrous; young shoots greenish. Tendrils: robust, simple or 2-3 fid, glabrous. Probracts minute. Leaves: petioles robust, sulcate, glabrous, 4-6 $\mathrm{cm}$ long, sometimes irregularly twisted; lamina glabrous, chartaceous, ovate-oblong or cordate in outline, 12$18(-25) \times 6-13(-22) \mathrm{cm}$, entire or occasionally 3-lobed/ angled, apex acuminate, base truncate-hastate or obtuse, 3-prominent nerved, margin denticulate or only remotely denticulate, glands few, minute, 10-20 along main nerves. Male inflorescences: glabrescent, 15-20 $\mathrm{cm}$ long, 12-20 flowered; rachis stout, striate; bracts glabrous, suborbicular-elliptic, $14-18 \times 5-8 \mathrm{~mm}$, slightly dentate, often 3-nerved. Male flowers: pedicels slender, puberulous, 2-4 mm long; calyx tube shortly tomentose, 2-3 cm long, dilated above, calyx lobe 5-7 × 1-2 mm, corolla yellowish-white. Female flowers not seen. Fruits: pedicels $8 \mathrm{~mm}$ long; fruits round-oblong, 8-12 $\times 4-5.5$ $\mathrm{cm}$, greenish-yellow at maturity, epicarp tough, pulp whitish. Seeds: dark brown or reddish-brown, oblongobovate, $2 \times 1.2 \times 0.3-0.4 \mathrm{~cm}$, base truncate, apex obtuse, compressed and narrowing towards margin.

Flowering and fruiting: May-August and JuneOctober, respectively.

Habitat: Degraded deciduous or evergreen forests, bamboo forests from 400-1,400 m.

Occurrence in India: Arunachal Pradesh, Assam, Meghalaya, Sikkim, West Bengal; new to Nagaland (Figure 1).

Distribution: Bangladesh, Bhutan, China, India, Myanmar, Thailand, and Vietnam.

Specimens examined: Nagaland: 13-1 (NHCP), 25.xi.2013, Longching, Mon dt., 1,350 m, Coll. K. Pradheep \& Soyimchiten.

Notes: Chakravarty (1982) and Renner \& Pandey (2013) mentioned this species from Andhra Pradesh which is outside its distribution range. Though type specimen was collected from Khasi Hills (almost 150 years ago), no further collections available thereafter and now failed to locate this species due to the extensive topographic change. This species could be a connecting link between Trichosanthes and Hodgsonia Hook.f. \& Thomson owing to the distinct characters big chartaceous leaves, yellowish-white flowers, bigsized fruits as well as seeds, and whitish mesocarp and pulp. Hajra et al. (1996) mentioned its occurrence from Kameng, Subansiri and Tirap in Arunachal Pradesh; however, we noticed it occasionally in Lohit district as well.

\section{REFERENCES}

Babu, C.R. (1977). Herbaceous Flora of Dehradun. Council of Scientific and Industrial Research, New Delhi, 721 pp.

Chakravarty, H.L. (1959). Monograph of Indian Cucurbitaceae (taxonomy and distribution). Records of the Botanical Survey of India 17: 1-234.

Chakravarty, H.L. (1982). Fascicles of the Flora of India: Cucurbitaceae, No. 11. Botanical Survey of India, Calcutta, 135 pp.

Dash, S.S. \& P. Singh (2017). Flora of Kurung Kumey District, Arunachal Pradesh. Botanical Survey of India, Kolkata, 782 pp.

de Wilde, W.J.J.O. \& B.E.E. Duyfjes (2010). Flora Malesiana, Series I, Seed Plants, Volume 19: Cucurbitaceae. National Herbarium Nederland, The Netherlands, $342 \mathrm{pp}$.

de Wilde, W.J.J.O. \& B.E.E. Duyfjes (2011). Keys to and checklist of species of the genus Trichosanthes L. (Cucurbitaceae) in Indochina. Adansonia 34(2): 265-278. http://sciencepress.mnhn.fr/sites/ default/files/articles/pdf/a2012n2a6.pdf

Duyfjes, B.E.E. \& K. Pruesapan (2004). The genus Trichosanthes L. (Cucurbitaceae) in Thailand. Thai Forest Bulletin (Botany) 32: 76-109. http://www.frc.forest.ku.ac.th/frcdatabase/bulletin/ Document/ThaiForestBulletin32 007.pdf

Grierson, A.J.C. \& D.G. Long (1991). Flora of Bhutan Including a Record of Plants from Sikkim. Vol. 2. Part 1. Royal Botanic Gardens, Edinburgh, UK, $426 \mathrm{pp}$.

Haines, H.H. (1921-1925). The Botany of Bihar and Orissa, 3 Vols. (reprint 1978). Bishen Singh Mahendra Pal Singh, Dehradun, 958 pp.

Hajra, P.K., D.M. Verma \& G.S. Giri (eds.) (1996). Materials for the Flora of Arunachal Pradesh. Vol. 1. Ranunculaceae-Dipsacaceae. Botanical Survey of India, Calcutta, 693 pp.

Hara, H. (1966). Flora of Eastern Himalaya, First Report. Tokyo University, Japan, $744 \mathrm{pp}$.

Huang, L.Q. \& C. Jeffrey (2011). Trichosanthes, pp. 36-45. In: Zhengyi, W., P.H. Raven \& H. Deyuan (eds.). Flora of China 19. Science Press, Beijing and Missouri Botanical Garden Press, St. Louis. http://www. efloras.org/florataxon.aspx?flora_id=2\&taxon_id=200022768

Jeffrey, C. (1980). Further notes on Cucurbitaceae: V. Cucurbitaceae of the Indian Subcontinent. Kew Bulletin 34: 789-809.

Jeffrey, C. (1982). Further notes on Cucurbitaceae: VI. Cucurbitaceae of the Indian Subcontinent. Kew Bulletin 36: 737-740.

Kanjilal, U.N., P.C. Kanjilal, R.N. De \& A. Das (1938). Flora of Assam (Reprint 1984), Vol. III. Caprifoliaceae-Plantaginaceae. Govt. of Assam, Shillong, $578 \mathrm{pp}$. 
Khanna, K.K., V. Mudgal, B.P. Uniyal \& J.R. Sharma (1999). Dicotyledonous Plants of Uttar Pradesh: A Checklist. Bishen Singh Mahenra Pal Singh, Dehra Dun, 455 pp.

Kundu, B.C. (1943). A revision of the Indian species of Hodgsonia and Trichosanthes. Journal of the Bombay Natural History Society 43: 362-388.

Mao, A.A., N. Odyuo, D. Verma \& P. Singh (2017). Checklist of Flora of Nagaland. Botanical Survey of India, Kolkata, 196 pp.

Naithani, H.B. (1990). Flowering Plants of India, Nepal and Bhutan: Not Recorded in Sir JD Hooker's Flora of British India. Surya Publications, Dehradun, $711 \mathrm{pp}$.

Pandey, S., Rana, T.S. \& K.N. Nair (2016). Revision of the Trichosanthes tricuspidata-bracteata complex (Cucurbitaceae) in India. Rheedea 26(2): 83-93. http://www.iaat.org.in/images/Rheedea_downloads/ Rheedea_26 2/Article-01_Trichosanthes.pdf

Paul, T.K., P. Lakshminarasimhan, H.J. Chowdhery, S.S. Dash \& P. Singh (eds.) (2015). Flora of West Bengal, Volume 2: Leguminosae to Aizoaceae. Botanical Survey of India, Kolkata, 455 pp.

Pradheep, K., A. Pandey \& D.C. Bhandari (2011). Notes on naturalized taxa of plant genetic resource value in Himachal Pradesh. Indian Journal of Plant Genetic Resources 24(1): 74-80.

Pradheep, K., A. Pandey, E.R. Nayar, Soyimchiten, S.P. Ahlawat \& R. Gupta (2018). Extended naturalization records of five non-native plant species to Indian states. Indian Journal of Plant Genetic Resources 31(1): 72-77.

Pradheep, K., D.C. Bhandari \& K.C. Bansal (2014). Wild Relatives of Cultivated Plants in India. Indian Council of Agricultural Research, New Delhi, 728 pp.

Pradheep, K., D.R. Pani \& K.C. Bhatt (2015). Taxonomic notes on the Trichosanthes cucumerina group (Cucurbitaceae) from India. Novon 24(1): 39-45.

Jain, S.K. \& R.R. Rao (1977). A Handbook of Field and Herbarium Methods. Today and Tomorrow Printers and Publishers, New Delhi, $157 \mathrm{pp}$.

Renner, S.S. \& A.K. Pandey (2013). The Cucurbitaceae of India: Accepted names, synonyms, geographic distribution, and information on images and DNA sequences. PhytoKeys 20: 53-118. https://www.ncbi. nlm.nih.gov/pmc/articles/PMC3652411/pdf/PhytoKeys-020-053.pdf

Rugayah (1999). Trichosanthes (Curcurbitaceae) in Malesia. Dissertation, Inst. Pertanian Bogor, Indonesia, $239 \mathrm{pp}$.

Saxena, H.O. \& M. Brahmam (1994-1996). The Flora of Orissa. Vol. I-IV. Orissa Forest Development Corporation Ltd, Bhubaneswar, India, $2918 \mathrm{pp}$.

Singh, N.P., A.S. Chauhan \& M.S. Mondal (eds.) (2000). Flora of Manipur, Vol. 1. Ranunculaceae-Asteraceae Botanical Survey of India, Kolkata, 600 pp.

Thiers, B. (2020 [continuously updated]) Index Herbariorum: A global directory of public herbaria and associated staff. Available from: http://sweetgum.nybg.org/ih/ (Electronic version accessed 12 June 2020)

Turland, N.J., J.H. Wiersema, F.R. Barrie, W. Greuter, D.L. Hawksworth, P.S. Herendeen, S. Knapp, W.-H. Kusber, D.-Z. Li, K. Marhold, T.W. May, J. McNeill, A.M. Monro, J. Prado, M.J. Price \& G.F. Smith (eds.) (2018). International Code of Nomenclature for algae, fungi, and plants (Shenzhen Code) adopted by the Nineteenth International Botanical Congress, Shenzhen, China, July 2017. Koeltz Botanical Books, Glashütten. https://doi.org/10.12705/Code.2018
Author details: DR. K. PRADHEEP is presently working as Principal Scientist at ICAR-NBPGR Regional Station, Thrissur, He is involved in Plant Genetic Resource (PGR) management activities in general, and germplasm collection and taxonomic studies in crop taxa, in particular. He has documented the Crop Wild Relatives (CWR) occurring in India. MR. SOYIMCHITEN is working as Scientist at the Division of Plant Exploration and Germplasm Collection, ICARNBPGR, New Delhi. He is specifically involved in collecting crop and CWR germplasm from all over the country. DR. G.D. HARISH is working as Scientist \& Officer-in-Charge at the ICAR-NBPGR, Regional Station, Shillong. He is working on the PGR management activities such as germplasm collection from northeastern states of the country, their conservation and evaluation at Shillong. DR. M. ABDUL NIZAR superannuated from service at ICAR-NBPGR, Regional Station, Thrissur. He has worked mainly on the PGR management activities such as germplasm collection from peninsular states of the country, their conservation and evaluation at Akola and Thrissur. DR. K.C. BHATT is working as Principal Scientist at the Division of Plant Exploration and Germplasm Collection, ICAR-NBPGR, New Delhi. $\mathrm{He}$ is specifically involved in collecting crop and CWR germplasm from all over the country. DR. ANJULA PANDEY is working as Principal Scientist at the Division of Plant Exploration and Germplasm Collection, ICAR-NBPGR, New Delhi. Besides, being the curator of National Herbarium of Cultivated Plants (NHCP), she is specifically involved in collecting crop and CWR germplasm and taxonomic research and teaching. DR. S.P. AHLAWAT is working as Head of the Division of Plant Exploration and Germplasm Collection, ICARNBPGR, New Delhi. He is coordinating exploration activities of ICAR-NBPGR, in addition to the involvement in the collecting of crop and CWR germplasm. 
Dr. John Noyes, Natural History Museum, London, UK

Dr. Albert G. Orr, Griffith University, Nathan, Australia

Dr. Sameer Padhye, Katholieke Universiteit Leuven, Belgium

Dr. Nancy van der Poorten, Toronto, Canada

Dr. Kareen Schnabel, NIWA, Wellington, New Zealand

Dr. R.M. Sharma, (Retd.) Scientist, Zoological Survey of India, Pune, India

Dr. Manju Siliwal, WILD, Coimbatore, Tamil Nadu, India

Dr. G.P. Sinha, Botanical Survey of India, Allahabad, India

Dr. K.A. Subramanian, Zoological Survey of India, New Alipore, Kolkata, India

Dr. P.M. Sureshan, Zoological Survey of India, Kozhikode, Kerala, India

Dr. R. Varatharajan, Manipur University, Imphal, Manipur, India

Dr. Eduard Vives, Museu de Ciències Naturals de Barcelona, Terrassa, Spain

Dr. James Young, Hong Kong Lepidopterists' Society, Hong Kong

Dr. R. Sundararaj, Institute of Wood Science \& Technology, Bengaluru, India

Dr. M. Nithyanandan, Environmental Department, La Ala Al Kuwait Real Estate. Co. K.S.C.,

Kuwait

Dr. Himender Bharti, Punjabi University, Punjab, India

Mr. Purnendu Roy, London, UK

Dr. Saito Motoki, The Butterfly Society of Japan, Tokyo, Japan

Dr. Sanjay Sondhi, TITLI TRUST, Kalpavriksh, Dehradun, India

Dr. Nguyen Thi Phuong Lien, Vietnam Academy of Science and Technology, Hanoi, Vietnam

Dr. Nitin Kulkarni, Tropical Research Institute, Jabalpur, India

Dr. Robin Wen Jiang Ngiam, National Parks Board, Singapore

Dr. Lional Monod, Natural History Museum of Geneva, Genève, Switzerland.

Dr. Asheesh Shivam, Nehru Gram Bharti University, Allahabad, India

Dr. Rosana Moreira da Rocha, Universidade Federal do Paraná, Curitiba, Brasi

Dr. Kurt R. Arnold, North Dakota State University, Saxony, Germany

Dr. James M. Carpenter, American Museum of Natural History, New York, USA

Dr. David M. Claborn, Missouri State University, Springfield, USA

Dr. Kareen Schnabel, Marine Biologist, Wellington, New Zealand

Dr. Amazonas Chagas Júnior, Universidade Federal de Mato Grosso, Cuiabá, Brasil

Mr. Monsoon Jyoti Gogoi, Assam University, Silchar, Assam, India

Dr. Heo Chong Chin, Universiti Teknologi MARA (UiTM), Selangor, Malaysia

Dr. R.J. Shiel, University of Adelaide, SA 5005, Australia

Dr. Siddharth Kulkarni, The George Washington University, Washington, USA

Dr. Priyadarsanan Dharma Rajan, ATREE, Bengaluru, India

Dr. Phil Alderslade, CSIRO Marine And Atmospheric Research, Hobart, Australia

Dr. John E.N. Veron, Coral Reef Research, Townsville, Australia

Dr. Daniel Whitmore, State Museum of Natural History Stuttgart, Rosenstein, Germany.

Dr. Yu-Feng Hsu, National Taiwan Normal University, Taipei City, Taiwan

Dr. Keith V. Wolfe, Antioch, California, USA

Dr. Siddharth Kulkarni, The Hormiga Lab, The George Washington University, Washington,

D.C., USA

Dr. Tomas Ditrich, Faculty of Education, University of South Bohemia in Ceske

Budejovice, Czech Republic

Dr. Mihaly Foldvari, Natural History Museum, University of Oslo, Norway

Dr. V.P. Uniyal, Wildlife Institute of India, Dehradun, Uttarakhand 248001, India

Dr. John T.D. Caleb, Zoological Survey of India, Kolkata, West Bengal, India

Dr. Priyadarsanan Dharma Rajan, Ashoka Trust for Research in Ecology and the Environment

(ATREE), Royal Enclave, Bangalore, Karnataka, India

\section{Fishes}

Dr. Neelesh Dahanukar, IISER, Pune, Maharashtra, India

Dr. Topiltzin Contreras MacBeath, Universidad Autónoma del estado de Morelos, México

Dr. Heok Hee Ng, National University of Singapore, Science Drive, Singapore

Dr. Rajeev Raghavan, St. Albert's College, Kochi, Kerala, India

Dr. Robert D. Sluka, Chiltern Gateway Project, A Rocha UK, Southall, Middlesex, UK

Dr. E. Vivekanandan, Central Marine Fisheries Research Institute, Chennai, India

Dr. Davor Zanella, University of Zagreb, Zagreb, Croatia

Dr. A. Biju Kumar, University of Kerala, Thiruvananthapuram, Kerala, India

Dr. Akhilesh K.V., ICAR-Central Marine Fisheries Research Institute, Mumbai Research

Centre, Mumbai, Maharashtra, India

Dr. J.A. Johnson, Wildlife Institute of India, Dehradun, Uttarakhand, India

Amphibians

Dr. Sushil K. Dutta, Indian Institute of Science, Bengaluru, Karnataka, India

Dr. Annemarie Ohler, Muséum national d'Histoire naturelle, Paris, France

\section{Reptiles}

Dr. Gernot Vogel, Heidelberg, Germany

Dr. Raju Vyas, Vadodara, Gujarat, India

Dr. Pritpal S. Soorae, Environment Agency, Abu Dubai, UAE.

Prof. Dr. Wayne J. Fuller, Near East University, Mersin, Turkey

Prof. Chandrashekher U. Rivonker, Goa University, Taleigao Plateau, Goa. India

Dr. S.R. Ganesh, Chennai Snake Park, Chennai, Tamil Nadu, India

Dr. Himansu Sekhar Das, Terrestrial \& Marine Biodiversity, Abu Dhabi, UAE
Birds

Dr. Hem Sagar Baral, Charles Sturt University, NSW Australia

Dr. Chris Bowden, Royal Society for the Protection of Birds, Sandy, UK

Dr. Priya Davidar, Pondicherry University, Kalapet, Puducherry, India

Dr. J.W. Duckworth, IUCN SSC, Bath, UK

Dr. Rajah Jayapal, SACON, Coimbatore, Tamil Nadu, India

Dr. Rajiv S. Kalsi, M.L.N. College, Yamuna Nagar, Haryana, India

Dr. V. Santharam, Rishi Valley Education Centre, Chittoor Dt., Andhra Pradesh, India

Dr. S. Balachandran, Bombay Natural History Society, Mumbai, India

Mr. J. Praveen, Bengaluru, India

Dr. C. Srinivasulu, Osmania University, Hyderabad, India

Dr. K.S. Gopi Sundar, International Crane Foundation, Baraboo, USA

Dr. Gombobaatar Sundev, Professor of Ornithology, Ulaanbaatar, Mongolia

Prof. Reuven Yosef, International Birding \& Research Centre, Eilat, Israel

Dr. Taej Mundkur, Wetlands International, Wageningen, The Netherlands

Dr. Carol Inskipp, Bishop Auckland Co., Durham, UK

Dr. Tim Inskipp, Bishop Auckland Co, Durham, UK

Dr. V. Gokula, National College, Tiruchirappalli, Tamil Nadu, India

Dr. Arkady Lelej, Russian Academy of Sciences, Vladivostok, Russia

Dr. Simon Dowell, Science Director, Chester Zoo, UK

Dr. Mário Gabriel Santiago dos Santos, Universidade de Trás-os-Montes e Alto Douro,

Quinta de Prados, Vila Real, Portugal

Dr. Grant Connette, Smithsonian Institution, Royal, VA, USA

Dr. M. Zafar-ul Islam, Prince Saud Al Faisal Wildlife Research Center, Taif, Saudi Arabia

Mammals

Dr. Giovanni Amori, CNR - Institute of Ecosystem Studies, Rome, Italy

Dr. Anwaruddin Chowdhury, Guwahati, India

Dr. David Mallon, Zoological Society of London, UK

Dr. Shomita Mukherjee, SACON, Coimbatore, Tamil Nadu, India

Dr. Angie Appel, Wild Cat Network, Germany

Dr. P.O. Nameer, Kerala Agricultural University, Thrissur, Kerala, India

Dr. Ian Redmond, UNEP Convention on Migratory Species, Lansdown, UK

Dr. Heidi S. Riddle, Riddle's Elephant and Wildlife Sanctuary, Arkansas, USA

Dr. Karin Schwartz, George Mason University, Fairfax, Virginia.

Dr. Lala A.K. Singh, Bhubaneswar, Orissa, India

Dr. Mewa Singh, Mysore University, Mysore, India

Dr. Paul Racey, University of Exeter, Devon, UK

Dr. Honnavalli N. Kumara, SACON, Anaikatty P.O., Coimbatore, Tamil Nadu, India

Dr. Nishith Dharaiya, HNG University, Patan, Gujarat, India

Dr. Spartaco Gippoliti, Socio Onorario Società Italiana per la Storia della Fauna "Giuseppe

Altobello", Rome, Italy

Dr. Justus Joshua, Green Future Foundation, Tiruchirapalli, Tamil Nadu, India

Dr. H. Raghuram, The American College, Madurai, Tamil Nadu, India

Dr. Paul Bates, Harison Institute, Kent, UK

Dr. Jim Sanderson, Small Wild Cat Conservation Foundation, Hartford, USA

Dr. Dan Challender, University of Kent, Canterbury, UK

Dr. David Mallon, Manchester Metropolitan University, Derbyshire, UK

Dr. Brian L. Cypher, California State University-Stanislaus, Bakersfield, CA

Dr. S.S. Talmale, Zoological Survey of India, Pune, Maharashtra, India

Prof. Karan Bahadur Shah, Budhanilakantha Municipality, Kathmandu, Nepal

Dr. Susan Cheyne, Borneo Nature Foundation International, Palangkaraja, Indonesia

Dr. Hemanta Kafley, Wildlife Sciences, Tarleton State University, Texas, USA

\section{Other Disciplines}

Dr. Aniruddha Belsare, Columbia MO 65203, USA (Veterinary)

Dr. Mandar S. Paingankar, University of Pune, Pune, Maharashtra, India (Molecular)

Dr. Jack Tordoff, Critical Ecosystem Partnership Fund, Arlington, USA (Communities)

Dr. Ulrike Streicher, University of Oregon, Eugene, USA (Veterinary)

Dr. Hari Balasubramanian, EcoAdvisors, Nova Scotia, Canada (Communities)

Dr. Rayanna Hellem Santos Bezerra, Universidade Federal de Sergipe, São Cristóvão, Brazil

Dr. Jamie R. Wood, Landcare Research, Canterbury, New Zealand

Dr. Wendy Collinson-Jonker, Endangered Wildlife Trust, Gauteng, South Africa

Dr. Rajeshkumar G. Jani, Anand Agricultural University, Anand, Gujarat, India

Dr. O.N. Tiwari, Senior Scientist, ICAR-Indian Agricultural Research Institute (IARI), New

Delhi, India

Dr. L.D. Singla, Guru Angad Dev Veterinary and Animal Sciences University, Ludhiana, India

Dr. Rupika S. Rajakaruna, University of Peradeniya, Peradeniya, Sri Lanka

Dr. Bahar Baviskar, Wild-CER, Nagpur, Maharashtra 440013, India

Reviewers 2018-2020

Due to pausity of space, the list of reviewers for $2018-2020$ is available online.

The opinions expressed by the authors do not reflect the views of the Journal of Threatened Taxa, Wildlife Information Liaison Development Society, Zoo Outreach Organization, or any of the partners. The journal, the publisher, the host, and the partners are not responsible for the accuracy of the political boundaries shown in the maps by the authors.

Journal of Threatened Taxa is indexed/abstracted in Bibliography of Systematic Mycology, Biological Abstracts, BIOSIS Previews, CAB Abstracts, EBSCO, Google Scholar, Index Copernicus, Index Fungorum, JournalSeek, National Academy of Agricultural Sciences, NewJour, OCLC WorldCat, SCOPUS, Stanford University Libraries, Virtual Library of Biology, Zoological Records.

NAAS rating (India) 5.64
Print copies of the Journal are available at cost. Write to:

The Managing Editor, JoTT,

c/o Wildlife Information Liaison Development Society,

No. 12, Thiruvannamalai Nagar, Saravanampatti - Kalapatti Road,

Saravanampatti, Coimbatore, Tamil Nadu 641035, India

ravi@threatenedtaxa.org 


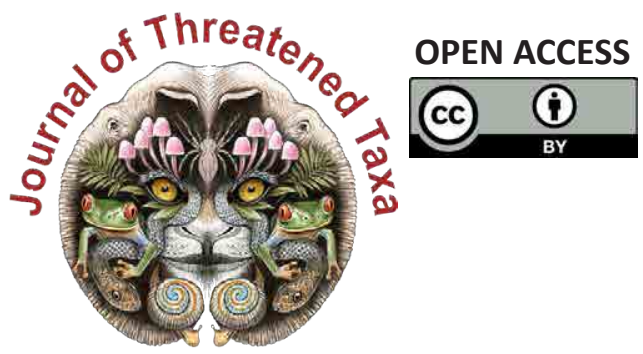

www.threatenedtaxa.org

The Journal of Threatened Taxa (JoTT) is dedicated to building evidence for conservation globally by publishing peer-reviewed articles online every month at a reasonably rapid rate at www.threatenedtaxa.org. All articles published in JoTT are registered under Creative Commons Attribution 4.0 International License unless otherwise mentioned. JoTT allows allows unrestricted use, reproduction, and distribution of articles in any medium by providing adequate credit to the author(s) and the source of publication.

\title{
ISSN $0974-7907$ (Online) | ISSN $0974-7893$ (Print)
}

\author{
December 2021 | Vol. 13 | No. 14 | Pages: 20143-20310 \\ Date of Publication: 26 December 2021 (Online \& Print) \\ DOI: 10.11609/jott.2021.13.14.20143-20310
}

\section{Communications}

Updated distribution of seven Trichosanthes L. (Cucurbitales: Cucurbitaceae) taxa in India, along with taxonomic notes

Kanakasabapathi Pradheep, Soyimchiten, Ganjalagatta Dasaiah Harish

Muhammed Abdul Nizar, Kailash Chandra Bhatt, Anjula Pandey \&

Sudhir Pal Ahlawat, Pp. 20143-20152

Dragonflies and Damselflies (Insecta: Odonata) of Aryanad Grama Panchayat, Kerala, India

- Reji Chandran \& A. Vivek Chandran, Pp. 20153-20166

Checklist of Odonata (Insecta) of Doon Valley, Uttarakhand, India

- Kritish De, Sarika Bhatt, Amar Paul Singh, Manisha Uniyal \& Virendra Prasad Uniyal, Pp. 20167-20173

Diversity of moths from the urban set-up of Valmiki Nagar, Chennai, India - Vikas Madhav Nagarajan, Rohith Srinivasan \& Mahathi Narayanaswamy, Pp. 20174-20189

Ichthyofaunal diversity with relation to environmental variables in the snowfed Tamor River of eastern Nepal

- Jawan Tumbahangfe, Jash Hang Limbu, Archana Prasad, Bhrarat Raj Subba \& Dil Kumar Limbu, Pp. 20190-20200

Observations on the foraging behavior of Tricoloured Munia Lonchura malacca (Linnaeus, 1766) and its interaction with pearl millet fields in Villupuram District, Tamil Nadu, India

- M. Pandian, Pp. 20201-20208

Roosting patterns of House Sparrow Passer domesticus Linn., 1758 (Aves:

Passeridae) in Bhavnagar, Gujarat, India

- Foram P. Patel \& Pravinsang P. Dodia, Pp. 20209-20217

Review

Comprehensive checklist of algal class Chlorophyceae (sensu Fritsch, 1935) for Uttar Pradesh, India, with updated taxonomic status

- Sushma Verma, Kiran Toppo \& Sanjeeva Nayaka, Pp. 20218-20248

\section{View Point}

Wildlife managers ignore previous knowledge at great risk: the case of Rivaldo, the iconic wild Asian Elephant Elephas maximus L. of the Sigur Region, Nilgiri Biosphere Reserve, India

- Jean-Philippe Puyravaud \& Priya Davidar, Pp. 20249-20252

\section{Short Communications}

Diversity and distribution of macro lichens from Kalpetta Municipality of Wayanad District, Kerala, India

- Greeshma Balu, A.R. Rasmi, Stephen Sequeira \& Biju Haridas, Pp. 20253-20257

Extended distribution of two endemic epiphytes from the Western Ghats to the Deccan Plateau

- Sonali Vishnu Deore, Mangala Dala Sonawane \& Sharad Suresh Kambale, Pp. 20258-20260

Nomenclatural notes and report of Boehmeria penduliflora Wedd. ex D.G. Long from the Terai region of Uttar Pradesh, India

- Amit Gupta, Imtiyaz Ahmad Hurrah, Aparna Shukla \& Vijay V. Wagh, Pp. 2026120265
New distribution record of a true coral species, Psammocora contigua (Esper, 1794) from Gulf of Kachchh Marine National Park \& Sanctuary, India - R. Chandran, R. Senthil Kumaran, D.T. Vasavada, N.N. Joshi \& Osman G. Husen, Pp. 20266-20271

A new species of flat-headed mayfly Afronurus meenmutti (Ephemeroptera: Heptageniidae: Ecdyonurinae) from Kerala, India

- Marimuthu Muthukatturaja \& Chellaiah Balasubramanian, Pp. 20272-20277

Photographic record of Dholes predating on a young Banteng in southwestern Java, Indonesia

- Dede Aulia Rahman, Mochamad Syamsudin, Asep Yayus Firdaus, Herry Trisna Afriandi \& Anggodo, Pp. 20278-20283

Latrine site and its use pattern by Large Indian Civet Viverra zibetha Linnaeus, 1758: record from camera trap

- Bhuwan Singh Bist, Prashant Ghimire, Basant Sharma, Chiranjeevi Khanal \& Anoj Subedi, Pp. 20284-20287

Notes

Two additions to the flora of Kerala, India

- P. Murugan, Basil Paul \& M. Sulaiman, Pp. 20288-20291

Pentatropis R.Br. ex Wight \& Arn. (Apocynaceae), a new generic record for Kerala, India

- V. Ambika, Jose Sojan \& V. Suresh, Pp. 20292-20294

New record of Kashmir Birch Mouse Sicista concolor leathemi (Thomas, 1893) (Rodentia: Sminthidae) in the Indian Himalaya

- S.S. Talmale, Avtar Kaur Sidhu \& Uttam Saikia, Pp. 20295-20298

Breeding record of Black-headed Ibis Threskiornis melanocephalus (Aves: Threskiornithidae) at Mavoor wetland, Kozhikode District, Kerala, India - C.T. Shifa, Pp. 20299-20301

\section{Response}

Crop and property damage caused by Purple-faced Langurs Trachypithecus vetulus (Mammalia: Primates: Cercopithecidae)

- Vincent Nijman, Pp. 20302-20306

Reply

If habitat heterogeneity is effective for conservation of butterflies in urban landscapes of Delhi, India? Unethical publication based on data manipulation: Response of original authors

- Monalisa Paul \& Aisha Sultana, Pp. 20307-20308

\section{Book Review}

Freshwater fishes of the Arabian Peninsula - Rajeev Raghavan, Pp. 20309-20310

Publisher \& Host

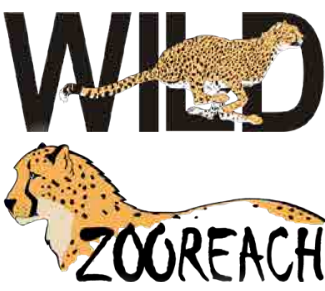

Threatened Taxa 